\title{
Iranian Language Teachers' and Students' Perspectives on Total English Series at Intermediate Level
}

\author{
Mehdi Azadsarv \\ English Department, Imam Khomeini University of Naval Sciences, Nowshahr, Iran \\ E-mail: Arasazadsarv@gmail.com \\ Mohammad Taghvaee \\ English Department, Imam Khomeini University of Naval Sciences, Nowshahr, Iran \\ E-mail: taghvaee2010@gmail.com \\ Ali Zangoei \\ University of Sistan and Baluchestan, Zahedan, Iran \\ E-mail: zangoei.ali@gmail.com
}

\section{Abstract}

As the means of transferring knowledge between teachers and students, coursebooks play a significant role in educational practices all over the world. Evaluation of coursebooks is also of great significance as it manages to a better understanding of the nature of a specific teaching/learning situation. The present study is an attempt to evaluate Total English coursebook from both Iranian EFL learners' and teachers' perspectives. Ninety three students and 20 teachers participated in this study. Fifty one of the students and 11 of the teachers were male and 42 of the students and nine of the teachers were female. The range of teachers' experience of teaching the coursebook was between 2-4 years and the range of students' experience of studying the coursebook was between 1-3 years. The data collection took place in three language institutes of Gilan and Mazandaran provinces. The coursebook, evaluated based on modified version of Cunningsworth's (1995) checklist, was the intermediate level of Total English. It was evaluated by both students and teachers based on administering written questionnaires. In order to triangulate the gathered data, 25 percent of the teachers and 10 percent of the students attended an interview session. Data analysis indicated that strength of Total English from teachers' perspective was culture and from students' point of view were visuals as well as practice and testing. Moreover, from students' perspective, the primary shortcoming of the coursebook was phonology.

Key words: course book; checklist; evaluation; Total English.

\section{Council for Innovative Research}

Peer Review Research Publishing System

Journal: Journal of Advances in Linguistics

Vol. 5, No. 1

editorjalonline@gmail.com

www.cirial.com 


\section{Introduction}

In the process of language teaching and learning, several components are involved in such as the learners, the teachers, the environment in which the learning event is taking place, the purpose of learning, and more importantly the textbooks, since they undoubtedly specify the main part of the teaching in the classroom and out-of-class learning of the students. Hutchinson and Torres (1994) state no teaching-learning situation is complete without adopting its appropriate textbook. Materials and textbooks serve as one of the main instruments for shaping knowledge, attitudes, and principles of the students (Nooreen \& Arshad, 2010).

Today, coursebooks are of vital significance to educational practices all over the world since they serve as the means of transferring knowledge between teachers and students. In addition, they are considered as the basis for much of the language input and the language practice which learners receive in the classroom. As Richards (2001) states, for learners the textbook might provide the main source of contact they maintain with the language. Litz (2005) asserts that whether one believes textbooks are too inflexible and biased to be used directly as instructional material, there can be no denying that they are still the most valuable element in educational systems. Garinger (2002) believes that a textbook can serve different purposes for teachers: as a core resource, as a source of supplemental material, as an inspiration for classroom activities, and even as the curriculum itself.

As a relatively new trend in the field of English language teaching (ELT), coursebook evaluation has attracted many language scholars' and curriculum developers' attention. Coursebooks have to be evaluated, since they are the basic materials in the learning process. The aim of textbook evaluation was to develop checklists based on which a book could be analyzed in detail in order to assure its usefulness and practicality with such factors as proficiency level of students, learners' needs, course objectives, gender, and many other contextual factors. (Najafi Sarem , Hamidi, \& Mahmoudie, 2013)

Tomlinson (2001) proposes coursebook evaluation is an applied linguistic activity through which teachers, supervisors, administrators and materials developers can make judgments about the effect of the materials on the people using them. Kiely (2009, p. 105) asserts that evaluation attempts to ensure "quality assurance and enhancement" and constructs "a dialogue within programs for ongoing improvement of learning opportunities." McGrath (2002) holds that coursebook evaluation is also of a significant value for the development and administration of language learning programs. Therefore, evaluating coursebooks in order to see whether they are suitable is of crucial significance.

Sheldon (1988) states coursebooks are the visible heart of any ELT program for both teachers and students; however, they are not free from shortcomings. Litz (2005) asserts that having dissatisfied textbook is due to the fact that they are often considered as the "tainted and product of an author's or a publisher's design for quick profit" (Sheldon, 1988, p.239).

Coursebooks are considered as significant resources for teachers and instructors in helping learners learn every subject including English. Finding an English institute without a coursebook is something surprising in Iran. Even some people compare different institutes and different teachers based on the coursebook they use in their English classes. Iranian students depend heavily on coursebooks and learn materials in a way that are displayed in their coursebooks; therefore, the content of textbook outweighs anything else.

Textbooks do not only influence what and how students learn, but also what and how teachers teach. Few teachers teach without a textbook that offers content and activities that form much of what occurs in a class. Nowadays textbooks play a very vital role in the dominion of language teaching and learning. In addition, after teachers, textbooks are considered to be the next significant aspect in the foreign language classroom. As Hutchinson and Torres (1994) believe, the textbook is an almost worldwide component of English language teaching. Millions of copies are sold yearly, and many aid plans have been set up to produce them in different countries.

McDonough and Shaw (2003) believe that there are several circumstances that it is needed to evaluate textbooks. The first is when the teachers might be given the choice to adopt or develop their materials and the second is when they are just users of other people's products. In both of these circumstances, some degree of evaluation is necessary. In EFL settings it can be discussed that the teacher and the textbook are the two most significant and immediate cultural links between the student's innate culture and the target foreign culture. If the dominant roles of the teacher and the textbook are accepted, then the way the textbook portrays the role of several people in the target society and the way they use language to express their meanings directly affect EFL students' choices of language when communicating with native speakers. Therefore, the materials and textbooks of each era in the history of ELT reflect the ethics and philosophies of a teaching method which were trendy at that time.

According to Sheldon (1988), we need to evaluate textbooks for two reasons; first, the evaluation will help the teacher or program developer in making decisions on selecting the appropriate textbook. Furthermore, evaluation of the merits and demerits of a textbook will familiarize the teacher with its probable weaknesses and strengths. This will enable teachers to make appropriate adaptations to the material in their future instruction.

Therefore, the present study is an attempt to address the issues mentioned above by determining the overall pedagogical value and suitability of the Total English coursebook from both Iranian EFL learners' and teachers' perspectives.

This study seeks answer to the following questions:

1. How is Total English series viewed from language teachers' and students' perspectives?

2. What are the strengths and weaknesses of Total English series? 


\section{Review of Literature}

English language teaching consists of significant components among which coursebooks and instructional materials are of vital importance in EFL/ESL classes and courses and are often employed by language teachers. Coursebook is a universal constituent of English language teaching. In ELT, coursebooks have always been one of the most preferred instructional resources. They are best viewed as a material in achieving goals and aims that have already been set concerning learner needs (Cunningsworth, 1995). In spite of the development of new technologies which makes highquality teacher-generated materials possible, a need for coursebooks grows every day, and new series of coursebooks are published every year (Lamie, 1999).

Ur (1996) defined coursebook as a textbook of which the teacher and, usually, each student has a copy, and which is in principle to be followed systematically as the basis for a language course. It also provides a clear framework. She proposed that coursebooks clarify subsequent materials and learners know where they are going. Due to having readymade texts and tasks, coursebooks save the time of the teacher. In addition, it guides the inexperienced teachers. Ur added that a textbook could provide the learner with some degree of autonomy. In other words, a learner without a textbook becomes more teacher-dependent.

In addition, coursebooks have a significant role to play in language classes in all educational settings: public schools, universities, and language schools. Razmjoo (2007) stated that working with a coursebook gives most students a sense of progress and achievement. Coursebooks are identified as an ineffective resource for self-directed learning and an effective resource for teacher-directed learning. Moreover, they are considered as a source of ideas and activities, a reference source for students, a syllabus that reflects predetermined learning objectives. They also serve as a support for the beginning teachers who have yet to gain in confidence (Cunningsworth, 1995).Therefore, it can be concluded that the basic role of coursebooks is to be at the service of teachers and learners but not their boss.

According to Daoud and Celce-Murcia (1979), it is useful to know some information on coursebook selection as sometimes it is teachers' duty to choose a coursebook which is going to be taught in a class. This selection should not be arbitrary; rather, it has to be careful and systematic. They also stated that even in places where teachers are not directly involved in coursebook selection, they might be asked to give reports on the effectiveness of the coursebooks they are already taking advantage of. Several criteria for selecting an appropriate coursebook have been offered although carrying out a sound selection of appropriate coursebooks is not a fully objective process. In spite of various guidelines which are offered, teachers' subjective judgments are central to coursebook selection. In materials selection, the materials have to be matched with goals and objectives of the program, and it is important to make certain that they are in line with one's beliefs about the nature of language and learning, as well as with one's learners' attitudes, beliefs, and preferences (ibid.).

Coursebook evaluation is an approximately new phenomenon in language teaching field. If coursebooks' values are accepted in English language teaching, it has to be with the qualification that they have acceptable level of quality, usefulness, and appropriateness for the context and people with whom they are being used. Coursebook evaluation and material selection is not an easy job. Effective evaluation of teaching materials is a very significant professional activity for all EFL/ESL teachers. Low (1989) stated that "designing appropriate material is not a science; it is a strange mixture of imagination, insight and analytical reasoning, and this fact must be recognized when materials are assessed" (p. 153).

Several scholars proposed various definitions and interpretations for coursebook evaluation. Coursebook evaluation typically functions as a sort of educational judgment. Richards, Platt, and Weber (1985) defined evaluation as "the systematic gathering of information for purposes of making decisions" (p. 98). Hutchinson and Waters (1987, p. 41) considered evaluation as "a matter of judging the fitness of something for a particular purpose." From Tomlinson's (1998) point of view, evaluation is the systematic judgment of the value of materials in relation to the purposes of the materials and the learners who are using them.

Coursebook evaluation is of great significance as it manages to a better understanding of the nature of a specific teaching/learning situation. In addition, it is of vital importance in education and for teachers as it gives them precious information for the future going of classroom practice, for the course planning, and for the management of learning tasks and students. Finally, evaluation is necessary for the use of instructional materials such as textbooks.

The most common method of conducting a coursebook evaluation is making use of an appropriate checklist that is developed by well-known scholars. While the subject of coursebook evaluation has not been extensively investigated, several authors have offered methods of assisting teachers to be more accurate in their evaluation by demonstrating evaluation checklists based on criteria which can be used by teachers and learners in various situations. Soori, Kafipour, and Soury (2011) defined checklist as an instrument which provides the evaluator with a list of features of successful teaching/learning materials.

Several scholars have conducted a detailed investigation of a textbook's language content that has managed to the production of large amounts of evaluation checklists. One of these checklists is Cunningsworth's (1984) checklist in which he touches upon the significance of relating coursebooks to course goals and the learners' needs and processes. Another one is Sheldon's (1988) checklist which includes a large variety of components and tries to evaluate all aspects of content such as graphics and physical characteristics to authenticity and flexibility.

In spite of Sheldon's (1988) suggestion that no list of criteria can really be used in all ESL/EFL settings without modification, most of these checklists include similar parts which can be applied as useful starting points for ELT teachers in various situations. Several scholars in the field of coursebook design like Sheldon (1988), Brown (1995), and Cunningsworth (1995) all assented that evaluation checklists ought to have some criteria related to the physical features 
of coursebook like layout, organizational, and logistical features as well. Other significant criteria which should be included are the criteria to evaluate a coursebook's methodology, objectives, approaches and the extent to which particular materials are not only teachable, but also are appropriate for both teacher's approach and organization's curriculum. In addition, criteria have to analyze the particular language functions, grammar, and skills which are covered by a specific coursebook and the relevance of linguistic elements to the socio-cultural context. Finally, coursebook evaluations have to contain criteria which are related to presentation of culture and gender as well as the degree to which the linguistic items, subjects, content, and topics fit the learner's personalities, backgrounds, needs, and interests as well as those of the teacher and/or institution.

A review of the literature indicates that most evaluation checklists have common characteristics. For example, Skierso's (1991) checklist contains features pertaining to bibliographical data, aims and goals, subject matter, vocabulary and structures, exercises and activities, and layout and physical makeup. These characteristics are mostly consistent with those in Cunningsworth's (1995) checklist which considers aims and approaches, design and organization, language content, skills, topic, methodology, and practical considerations. Even though the topic of the parts in the two checklists seem different, an investigation of the items will display that they are approximately similar. For instance, Skierso (1991) considers the cost-effectiveness of the coursebook in the section named 'bibliographical data', while Cunningsworth (1995) refers to it in the 'practical consideration' section. Daoud and Celce-Murcia (1979) proposed a checklist for coursebook evaluation which includes five main parts: subject matter, vocabulary and structures, exercises, illustrations, and physical make-up. Every part consists of detailed strategies that can be used in assessing and analyzing every coursebook.

The checklist used in the present study was a coursebook evaluation checklist which was primarily designed by Cunningsworth (1995) and specifically modified for this study. Cunningsworth (1995) stated that since "different criteria will apply in different circumstances" (p. 2), teachers and researchers ought to identify their own priorities and develop their own checklists. The checklist used in this study consists of fifty three criteria in fourteen sections; content, grammar, vocabulary, phonology, language skills, methodology, study skills, visuals, practice and testing, supplementary material, objectives, content selection, gradation, and culture. Moreover, the checklist has a four-point multiple-choice Likert scale format.

\section{Method}

\subsection{Participants}

The participants of this study were selected from various language institutes of Gilan and Mazandaran provinces in which Total English coursebook was taught. Three institutes were selected randomly. Ninety three students and 20 teachers participated in this study. Fifty one of the students and 11 of the teachers were male and 42 of the students and nine of the teachers were female. The range of teachers' experience of teaching the coursebook was between 2-4 years and the range of students' experience of studying the coursebook was between 1-3 years.

\subsection{Instruments}

The instruments employed in this study are students' and teachers' checklists modified from Cunningsworth (1995).

\subsubsection{Checklist}

The checklist employed in the present study was developed mainly from Cunningsworth's (1995) checklist after tailoring it to meet the objectives of this study. Some of the items of the questionnaire were modified and some were removed from the questionnaire since they did not suit Iran's context. These modifications were made based on the interviews that the researcher had with four TEFL experts. Cunningsworth (1995) proposed that as "different criteria will apply in different circumstances" (p. 2), teachers or researchers ought to specify their own priorities and prepare their own checklists. Sheldon (1988) states "any culturally restricted, global list of criteria can never really apply in most local environments, without considerable modification" (p. 242). Therefore, the items of the cultural section of the questionnaire were taken from Shatery and Azargoon's (2012) nativized checklist.

The checklist used in the study includes 53 criteria in 14 categories: content, grammar, vocabulary, phonology, language skills, methodology, study skills, visuals, practice and testing, supplementary material, objectives, content selection, gradation, and culture. It was used to indicate participants' opinions regarding the four coursebooks used in the study. A four-point multiple-choice Likert scale format, ranging 1-4, was used to show participants' level of agreement with a list of statements. Each statement was weighted equally ( 1 point for each strongly disagree, 2 points for each disagree, 3 points for each agree, and 4 points for each strongly agree). All scores were converted to percentile rankings (0-100\%).

Students and teachers completed the same version of checklist, to allow for comparison across groups, although the teachers' version included some additional items. One of the benefits of employing a single questionnaire was avoiding linguistic and cultural biases, and also achieving results which were as precise as possible. While both questionnaires included nine common categories (statements 1-30) - content, grammar, vocabulary, phonology, language skills, methodology, study skills, visuals, and practice and testing- the teachers' questionnaire had five additional categories: supplementary material, objectives, content selection, gradation, and culture (statements 31-53). Both questionnaires had an open-ended section where participants were given the opportunity to write their own comments or suggestions regarding the coursebook. Finally, the researcher reviewed the coursebook thoroughly to provide a descriptive analysis of the 14 categories. 
In addition to English statements, students' checklist was accompanied by Persian translation of the statements in order to remove any ambiguities for students in understanding the statements of the questionnaire. In order to ensure the validity of the checklist's translation, the researcher asked a translation expert to translate the questionnaire into Persian. The Persian translations were translated into English by three experts. The comparison of these three translated checklists with the original one showed no considerable difference; therefore, it was concluded that the Persian translation of the checklist was valid.

\subsubsection{Pilot study}

In order to estimate how reliable the use of the checklist is, the researcher administered the checklist to the pilot group of 30 students and 30 teachers. Cronbach's Alpha was used for the computation of the internal consistency of the checklist. The reliability index for the present study's checklist was found to be 0.94 , for students' questionnaire and 0.86 for teachers' questionnaire, both are considered high reliabilities.

To ensure the content and face validity of the checklist, the comments of five experts were sought. Each strongly confirmed the appropriateness of the checklist in regard to the general objective of evaluating coursebooks.

It is worth mentioning that the researcher took advantage of the students' and the teachers' comments and suggestions about the questionnaire and applied some slight modifications in the final version.

\subsection{Procedure}

This study aimed at evaluating the most frequently used foreign coursebook in Iran, namely Total English. The data collection took place in three institutes of Gilan and Mazandaran provinces. The coursebook, evaluated based on the evaluation checklist, was the intermediate level of Total English. The textbook was evaluated by both students and teachers based on administering written questionnaires. The researcher requested institutes' supervisors for permission to administer the research instruments in the selected classes in collaboration with class teachers. The questionnaires were administered and collected in one session. The researcher himself attended administration sessions in order to clarify any probable ambiguities for students and teachers. Before administering the questionnaire, the project was explained to the participants in the study in order to guarantee their cooperation. All the participants were given an oral description of objectives and procedures of the questionnaire. They were also assured that the results would be kept confidential. They had ample amount of time to go over the questionnaire items and answer them.

In order to empower the gathered data, 25 percent of the teachers and 10 percent of the students attended to an interview session. The researchers' final insights and overall evaluation of the coursebooks were made in section four after analyzing the gathered data. In this section, the weakness and strengths of the coursebook were discussed. Once the data were collected, appropriate statistical tests were used to find out the significance of the results.

\subsection{Data Analysis}

In order to analyze the collected data from the questionnaires, first of all descriptive statistics including means and standard deviations were computed to summarize the students' responses to the checklists. In addition, chi squares were run to see whether the differences in each item were meaningful or not. Moreover, the interviews that included openended items were analyzed qualitatively. It must be noted that all the statistical analyses were conducted by using the Statistical Package for Social Sciences (SPSS 17.0) program. Hypotheses were tested on alpha .05. Finally, the results were interpreted and discussed and their implications were also pointed out.

\section{Results}

In this section, all the administered questionnaires from both teachers' and students' perspectives were analyzed and their reports were presented.

\subsection{Analysis of the Questionnaires}


Table 1

Result of the descriptive statistics, percentage and Chi-square of the teachers' responses related to content

\begin{tabular}{|c|c|c|c|c|c|c|c|c|c|c|c|}
\hline \multirow[b]{3}{*}{1.} & \multirow[b]{3}{*}{$\begin{array}{l}\text { The selected topics are familiar to the } \\
\text { students. }\end{array}$} & \multirow{3}{*}{$\frac{N}{20}$} & \multirow{3}{*}{$\begin{array}{l}\text { Mean } \\
2.95\end{array}$} & \multirow{3}{*}{$\begin{array}{c}\begin{array}{c}\text { Std. } \\
\text { Deviation }\end{array} \\
.22\end{array}$} & \multicolumn{4}{|c|}{ Percentage } & \multirow[b]{2}{*}{$\begin{array}{l}\text { Chi- } \\
\text { square }\end{array}$} & \multirow{2}{*}{\multicolumn{2}{|c|}{$\begin{array}{l}\text { df Asymp. } \\
\text { Sig. }\end{array}$}} \\
\hline & & & & & $\begin{array}{l}\text { S. } \\
\text { Agr. }\end{array}$ & Agr. & D.Agr & $\begin{array}{l}\text { S. D. } \\
\text { Agr }\end{array}$ & & & \\
\hline & & & & & 0 & 95 & 5 & 0 & 16.20 & 1 & .00 \\
\hline 2. & $\begin{array}{l}\text { The selected topics enhance learners' } \\
\text { motivation. }\end{array}$ & 20 & 2.85 & .36 & 0 & 85 & 15 & 0 & 9.80 & 1 & .00 \\
\hline 3. & $\begin{array}{l}\text { The CB contains adequate self-check } \\
\text { progress report. }\end{array}$ & 20 & 2.60 & .68 & 5 & 55 & 35 & 5 & 14.40 & 3 & .00 \\
\hline & $\begin{array}{l}\text { 4. Texts and dialogues include new } \\
\text { vocabulary and grammatical structures. }\end{array}$ & 20 & 2.90 & .78 & 20 & 55 & 20 & 5. & 10.80 & 3 & .01 \\
\hline 5. & $\begin{array}{c}\text { Language items (e.g. vocabulary, etc) are } \\
\text { presented in context to make meaning } \\
\text { clear. }\end{array}$ & 19 & 2.89 & .31 & 0 & 89.5 & 10.5 & 0 & 11.84 & 1 & .00 \\
\hline 6. & $\begin{array}{l}\text { Pedagogic texts and dialogues include a } \\
\text { variety of interesting subjects. }\end{array}$ & 20 & 2.45 & .60 & 5 & 35 & 60 & 0 & 9.10 & 2 & .11 \\
\hline
\end{tabular}

Note. S. Agr. $=$ Strongly Agree; Agr. = Agree; D. Agr. = Disagree; S. D. Agr. $=$ Strongly

As it is indicated in table 1 , in item $1,95 \%$ of the teachers agreed and $5 \%$ of them disagreed that the selected topics are familiar to the students $(M=2.95, S D=.22)$. Moreover, there is a significant difference between the number of teachers who agreed and the ones who disagreed with this item, $c^{2}(1, N=20)=16.20, p<.05$.

In the second item, $85 \%$ of the teachers agreed and $15 \%$ of them disagreed that the selected topics enhance learners' motivation ( $\mathrm{M}=2.85, \mathrm{SD}=.36)$. In addition, there is a significant difference between the number of teachers who agreed and the ones who disagreed with this item, $c^{2}(1, N=20)=9.80, p<.05$.

The next item considers whether Total English coursebook contains adequate self-check progress report or not. The results show that $5 \%$ of the teachers strongly agreed and $55 \%$ of them agreed that the coursebook contains adequate self-check progress report. In addition, $35 \%$ of the teachers disagreed and $5 \%$ of them strongly disagreed with this item $(\mathrm{M}=2.60$, SD=.68; SUM. of S. Agr. \& Agr. $=60 \%)$. Moreover, there is a significant difference between the number of teachers who agreed and the ones who strongly agreed, disagreed and strongly disagreed with this item, $\mathrm{c}^{2}(3, \mathrm{~N}=$ 20) $=14.40, p<.05$.

The findings in item 4 display that $20 \%$ of the teachers strongly agreed and the $55 \%$ of them agreed that texts and dialogues include new vocabulary and grammatical structures. In addition, $20 \%$ of the teachers disagreed and $5 \%$ of them strongly disagreed with this item $(\mathrm{M}=2.90, \mathrm{SD}=.78$; SUM. of $\mathrm{S}$. Agr. \& Agr. $=75 \%)$. Moreover, there is a significant difference between the number of teachers who agreed and the ones who strongly agreed, disagreed and strongly disagreed with this item, $\mathrm{c}^{2}(3, \mathrm{~N}=20)=10.80, \mathrm{p}<.05$.

The fifth item considers if language items (e.g. vocabulary, etc.) are presented in context to make meaning clear. The results show that $89.5 \%$ of the teachers agreed and $10.5 \%$ of them disagreed that the language items (e.g. vocabulary, etc.) are presented in context to make meaning clear $(\mathrm{M}=2.89, \mathrm{SD}=.31)$. Moreover, there is a significant difference between the number of teachers who agreed and the ones who disagreed with this item, $c^{2}(1, N=19)=11.84, p<.05$. 
In the last item of this category, $5 \%$ of the teachers strongly agreed and $35 \%$ of them agreed that pedagogic texts and dialogues include a variety of interesting subjects. In addition, $60 \%$ of the teachers disagreed with this item $(\mathrm{M}=2.45$, $\mathrm{SD}=.60$; SUM. of D. Agr. \& S. D. Agr. $=60 \%$ ). Moreover, there is no significant difference between the number of teachers who disagreed and the ones who strongly agreed and agreed with this item, $c^{2}(2, N=20)=9.10, p>.05$.

Table 2

Result of the descriptive statistics, percentage and Chi-square of the students' responses related to content

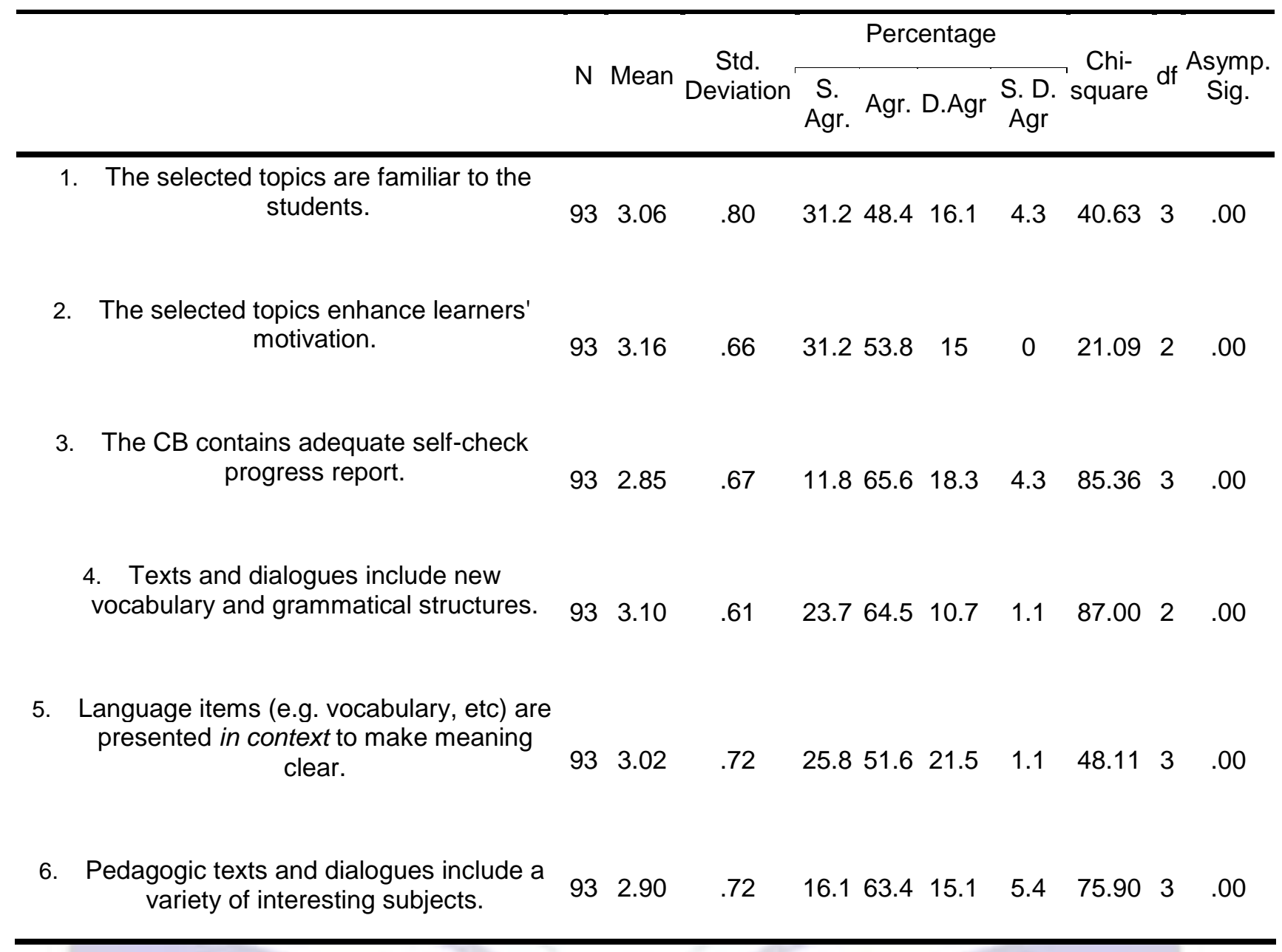

As it is indicated in table 2, in item 1, 31.2\% of the students strongly agreed and $48.4 \%$ of them agreed that the selected topics are familiar to the students. In addition, $16.1 \%$ of the students disagreed and $4.3 \%$ of them strongly disagreed with this item ( $\mathrm{M}=3.6, \mathrm{SD}=.80$; SUM. of S. Agr. \& Agr. =79.6\%). Moreover, there is a significant difference between the number of students who agreed and the ones who strongly agreed, disagreed, and strongly disagreed with this item, $c^{2}(3, N=93)=40.63, p<.05$.

Item 2 considers if the selected topics enhance learners' motivation. The results show that $31.2 \%$ of the students strongly agreed and $53.8 \%$ of them agreed that the selected topics enhance learners' motivation. In addition, $15 \%$ of the students disagreed with this item ( $\mathrm{M}=3.16, \mathrm{SD}=.66$; SUM. of S. Agr. \& Agr. $=85 \%)$. Moreover, there is a significant difference between the number of students who agreed and the ones who strongly agreed and disagreed with this item, $\mathrm{c}^{2}(2, \mathrm{~N}=$ 93) $=21.09, \mathrm{p}<.05$.

In the third item, $11.8 \%$ of the students strongly agreed and $65.6 \%$ of them agreed that Total English coursebook contains adequate self-check progress report. In addition, $18.3 \%$ of the students disagreed and $4.3 \%$ of them strongly disagreed with this item ( $\mathrm{M}=2.85, \mathrm{SD}=.67$; SUM. of S. Agr. \& Agr. $=77.4 \%)$. Moreover, there is a significant difference between the number of students who agreed and the ones who strongly agreed, disagreed, and strongly disagreed with this item, $c^{2}(3, N=93)=85.36, p<.05$.

Item 4 considers whether texts and dialogues include new vocabulary and grammatical structures or not. Data analysis shows that $23.7 \%$ of the students strongly agreed and $64.5 \%$ of them agreed that texts and dialogues include new vocabulary and grammatical structures. In addition, $10.7 \%$ of the students disagreed and $1.1 \%$ of them strongly disagreed with this item $(\mathrm{M}=3.10, \mathrm{SD}=.61$; SUM. of $\mathrm{S}$. Agr. \& Agr. $=88.2 \%)$. Moreover, there is a significant difference 
between the number of students who agreed and the ones who strongly agreed, disagreed, and strongly disagreed with this item, $c^{2}(3, N=93)=87.00, p<.05$.

In item $5,25.8 \%$ of the students strongly agreed and $51.6 \%$ of them agreed that language items (e.g. vocabulary, etc) are presented in context to make meaning clear. In addition, $21.5 \%$ of the students disagreed and $1.1 \%$ of them strongly disagreed with this item $(\mathrm{M}=2.93, \mathrm{SD}=.90$; SUM. of $\mathrm{S}$. Agr. \& Agr. $=77.4 \%)$. Moreover, there is a significant difference between the number of students who agreed and the ones who strongly agreed, disagreed, and strongly disagreed with this item, $\mathrm{c}^{2}(3, \mathrm{~N}=93)=48.11, \mathrm{p}<.05$

In the sixth item, $16.1 \%$ of the students strongly agreed and $63.4 \%$ of them agreed that pedagogic texts and dialogues include a variety of interesting subjects. In addition, $15.1 \%$ of the students disagreed and $5.4 \%$ of them strongly disagreed with this item $(\mathrm{M}=2.90, \mathrm{SD}=.72$; SUM. of S. Agr. \& Agr. $=79.5 \%)$. Moreover, there is a significant difference between the number of students who agreed and the ones who strongly agreed, disagreed, and strongly disagreed with this item, $c^{2}(3, N=93)=75.90, p<.05$.

Table 3

Result of the descriptive statistics, percentage and Chi-square of the teachers' responses related to grammar

\begin{tabular}{|c|c|c|c|c|c|c|c|c|c|c|}
\hline & \multirow[b]{2}{*}{$\mathrm{N}$} & \multirow[b]{2}{*}{ Mean } & \multirow[b]{2}{*}{$\begin{array}{c}\text { Std. } \\
\text { Deviation }\end{array}$} & \multicolumn{4}{|c|}{ Percentage } & \multirow[b]{2}{*}{$\begin{array}{l}\text { Chi- } \\
\text { square }\end{array}$} & & \multirow[b]{2}{*}{$\begin{array}{c}\text { Asymp. } \\
\text { Sig. }\end{array}$} \\
\hline & & & & $\begin{array}{l}\text { S. } \\
\text { Agr. }\end{array}$ & Agr. & D.Agr & $\begin{array}{l}\text { S. D. } \\
\text { Agr }\end{array}$ & & & \\
\hline $\begin{array}{l}\text { 7. The paradigm used to introduce grammatical } \\
\text { rules is clear and simple. }\end{array}$ & 20 & 2.70 & .65 & 10 & 50 & 40 & 0 & 5.20 & 2 & .07 \\
\hline 8. Grammar items suit students' language needs. & 20 & 2.70 & .57 & 0 & 75 & 20 & 5 & 16.30 & 2 & .00 \\
\hline 9. There is a balance between form and use. & 20 & 2.90 & .55 & 10 & 70 & 20 & 0 & 12.40 & 2 & .00 \\
\hline $\begin{array}{l}\text { 10. Sentences and examples contain words that are } \\
\text { known by learners. }\end{array}$ & 20 & 2.90 & .44 & 5 & 80 & 15 & 0 & 19.90 & 2 & .00 \\
\hline
\end{tabular}

As displayed in table 3, in item 7, $10 \%$ of the teachers strongly agreed and $50 \%$ of them agreed that the paradigm used to introduce grammatical rules is clear and simple. In addition, $40 \%$ of the teachers disagreed with the item ( $M=2.70, S D=.65$; SUM. of S. Agr. \& Agr. $=60 \%)$. Moreover, there is no significant difference between the number of teachers who agreed and the ones who strongly agreed and disagreed with this item, $c^{2}(2, N=20)=5.20, p>.05$.

The eighth item considers whether grammar items suit students' language needs. The results show that $75 \%$ of the teachers agreed that grammar items suit students' language needs. Moreover, $20 \%$ of the teachers disagreed and $5 \%$ of them strongly disagreed with this item ( $\mathrm{M}=2.70, \mathrm{SD}=.57$; SUM. of S. Agr. \& Agr. $=75 \%)$. In addition, there is a significant difference between the number of teachers who agreed and the ones who disagreed and strongly disagreed with this item, $c^{2}(2, N=20)=16.30, p<.05$.

In item $9,10 \%$ of the teachers strongly agreed and $70 \%$ of them agreed that there is a balance between form and use. In addition, $20 \%$ of the teachers disagreed with this item ( $\mathrm{M}=2.90, \mathrm{SD}=.55$; SUM. of S. Agr. \& Agr. $=80 \%)$. Moreover, there is a significant difference between the number of teachers who agreed and the ones who strongly agreed and disagreed with this item, $c^{2}(2, N=20)=12.40, p<.05$.

Item 10 considers if sentences and examples contain words that are known by learners. The findings display that $5 \%$ of the teachers strongly agreed and $80 \%$ of them agreed that sentences and examples contain words that are known by learners. In addition, $15 \%$ of the teachers disagreed with this item ( $\mathrm{M}=2.90, \mathrm{SD}=.44$; SUM. of $\mathrm{S}$. Agr. \& Agr. $=85 \%$ ). Moreover, there is a significant difference between the number of teachers who agreed and the ones who strongly agreed and disagreed with this item, $c^{2}(2, N=20)=19.90, p<.05$. 
Table 4

Result of the descriptive statistics, percentage and Chi-square of the students' responses related to grammar

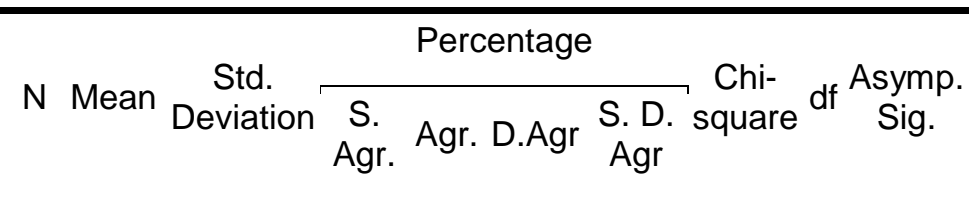

7. The paradigm used to introduce

grammatical rules is clear and simple.

$\begin{array}{llllllllll}93 & 3.07 & .72 & 26.9 & 57 & 12.9 & 3.2 & 61.28 & 3 & .00\end{array}$

8. Grammar items suit students' language needs.

$\begin{array}{llllllllll}93 & 2.97 & .69 & 18.3 & 65.6 & 11.8 & 4.3 & 85.36 & 3 & .00\end{array}$

9. There is a balance between form and use.

$\begin{array}{llllllllll}93 & 3.09 & .82 & 33.3 & 48.4 & 12.9 & 5.4 & 42.69 & 3 & .00\end{array}$

10. Sentences and examples contain words that are known by learners.

Table 4 indicates that in item 7, 26.9\% of the students strongly agreed and $57 \%$ of them agreed that the paradigm used to introduce grammatical rules is clear and simple. In addition, $12.9 \%$ of the students disagreed and $3.2 \%$ of them strongly disagreed with this item $(\mathrm{M}=3.07, \mathrm{SD}=.72$; SUM. of $\mathrm{S}$. Agr. \& Agr. = 83.9\%). Moreover, there is a significant difference between the number of students who agreed and the ones who strongly agreed, disagreed, and strongly disagreed with this item, $c^{2}(3, N=93)=61.28, p<.05$.

Item 8 considers if grammar items suit students' language needs. The findings indicate that $18.3 \%$ of the students strongly agreed and $65.6 \%$ of them agreed that grammar items suit students' language needs. In addition, $11.8 \%$ of the students disagreed and $4.3 \%$ of them strongly disagreed with this item (M = 2.97, SD=.69; SUM. of S. Agr. \& Agr. = $83.9 \%$ ). Moreover, there is a significant difference between the number of students who agreed and the ones who strongly agreed, disagreed, and strongly disagreed with this item, $c^{2}(3, N=93)=85.36, p<.05$.

In the next item, $33.3 \%$ of the students strongly agreed and $48.4 \%$ of them agreed that there is a balance between form and use. In addition, $12.9 \%$ of the students disagreed and $5.4 \%$ of them strongly disagreed with this item $(\mathrm{M}=3.09$, $\mathrm{SD}=.82$; SUM. of S. Agr. \& Agr. $=81.7 \%$ ). Moreover, there is a significant difference between the number of students who agreed and the ones who strongly agreed, disagreed, and strongly disagreed with this item, $c^{2}(3, N=93)=42.69, p$ $<.05$.

The last item of this category demonstrates that $28 \%$ of the students strongly agreed and $51.6 \%$ of them agreed that sentences and examples contain words that are known by learners. In addition, $12.9 \%$ of the students disagreed and 7.5 $\%$ of them strongly disagreed with this item $(\mathrm{M}=3.00, \mathrm{SD}=.84$; SUM. of $\mathrm{S}$. Agr. \& Agr. $=79.6 \%)$. Moreover, there is a significant difference between the number of students who agreed and the ones who strongly agreed, disagreed, and strongly disagreed with this item, $c^{2}(3, N=93)=43.47, p<.05$. 
Table 5

Result of the descriptive statistics, percentage and Chi-square of the teachers' responses related to vocabulary

\begin{tabular}{|c|c|c|c|c|c|c|c|c|c|}
\hline & \multirow[b]{2}{*}{$N$} & \multirow[b]{2}{*}{ Mean } & \multirow[b]{2}{*}{$\begin{array}{c}\text { Std. } \\
\text { Deviation }\end{array}$} & \multicolumn{4}{|c|}{ Percentage } & \multirow{2}{*}{$\begin{array}{l}\text { Chi- } \\
\text { squar df } \\
\text { e }\end{array}$} & \multirow[b]{2}{*}{$\begin{array}{l}\text { Asym } \\
\text { p. Sig. }\end{array}$} \\
\hline & & & & $\begin{array}{l}\text { S. } \\
\text { Agr. }\end{array}$ & Agr & $\begin{array}{l}\text { D.A } \\
\text { gr }\end{array}$ & $\begin{array}{l}\text { S. D. } \\
\text { Agr }\end{array}$ & & \\
\hline $\begin{array}{l}\text { 11. New lexical items appear in the following } \\
\text { units. }\end{array}$ & 20 & 2.85 & .81 & 20 & 50 & 25 & 5 & 8.403 & .03 \\
\hline $\begin{array}{l}\text { 12. The exercises for vocabulary are rich and } \\
\text { adequate. }\end{array}$ & 20 & 2.45 & .51 & 0 & 45 & 55 & 0 & .201 & .65 \\
\hline
\end{tabular}

Table 5 shows that in item 11, 20\% of the teachers strongly agreed and $50 \%$ of them agreed that new lexical items appear in the following units. In addition, $25 \%$ of the teachers disagreed and $5 \%$ of them strongly disagreed with the item $(\mathrm{M}=2.85, \mathrm{SD}=.81$; SUM. of $\mathrm{S}$. Agr. \& Agr. $=70 \%)$. Moreover, there is a significant difference between the number of teachers who agreed and the ones who strongly agreed, disagreed, and strongly disagreed with this item, $c^{2}(3, N=$ 20) $=8.40, p<.05$.

Twelfth item considers whether the exercises for vocabulary are rich and adequate or not. The results display that $45 \%$ of the teachers agreed and $55 \%$ of them disagreed that the exercises for vocabulary are rich and adequate $(M=2.45$, $\mathrm{SD}=.51$ ). Moreover, there is no significant difference between the number of teachers who agreed and the ones who disagreed with this item, $c^{2}(1, N=20)=.20, p>.05$.

Table 6

Result of the descriptive statistics, percentage and Chi-square of the students' responses related to vocabulary

\begin{tabular}{|c|c|c|c|c|c|c|c|c|c|}
\hline & \multirow[b]{2}{*}{$\mathrm{N}$} & \multirow[b]{2}{*}{ Mean } & \multirow[b]{2}{*}{$\begin{array}{c}\text { Std. } \\
\text { Deviation }\end{array}$} & \multicolumn{4}{|c|}{ Percentage } & \multirow{2}{*}{$\begin{array}{l}\text { Chi- } \\
\text { squar df } \\
\text { e }\end{array}$} & \multirow[b]{2}{*}{$\begin{array}{l}\text { Asym } \\
\text { p. Sig. }\end{array}$} \\
\hline & & & & $\begin{array}{l}\text { S. } \\
\text { Agr. }\end{array}$ & Agr & $\begin{array}{l}\text { D.A } \\
\text { gr }\end{array}$ & $\begin{array}{l}\text { S. D. } \\
\text { Agr }\end{array}$ & & \\
\hline $\begin{array}{l}\text { 11. New lexical items appear in the following } \\
\text { units. }\end{array}$ & 89 & 2.64 & .82 & 15.7 & $\begin{array}{c}39 . \\
3\end{array}$ & $\begin{array}{c}38 . \\
3\end{array}$ & 6.7 & 28.433 & .00 \\
\hline $\begin{array}{l}\text { 12. The exercises for vocabulary are rich and } \\
\text { adequate. }\end{array}$ & 93 & 2.68 & .82 & 16.1 & 43 & $\begin{array}{c}34 . \\
4\end{array}$ & 6.5 & 31.083 & .00 \\
\hline
\end{tabular}

As displayed in table 6, in item 11, 15.7\% of the students strongly agreed and $39.3 \%$ of them agreed that new lexical items appear in the following units. In addition, 38.3\% of the students disagreed and $6.7 \%$ of them strongly disagreed with this item $(M=2.64, \mathrm{SD}=.82$; SUM. of $\mathrm{S}$. Agr. \& Agr. $=55 \%)$. Moreover, there is a significant difference between the number of students who agreed and the ones who strongly agreed, disagreed, and strongly disagreed with this item, $c^{2}(3, N=93)=28.43, p<.05$.

Item 12 considers whether the exercises for vocabulary are rich and adequate or not. Data analysis indicates that $16.1 \%$ of the students strongly agreed and $43 \%$ of them agreed that the exercises for vocabulary are rich and adequate. In addition, $34.4 \%$ of the students disagreed and $6.5 \%$ of them strongly disagreed with this item $(M=2.68, S D=.82 ; S U M$. of S. Agr. \& Agr. $=59.1 \%$ ). Moreover, there is a significant difference between the number of students who agreed and the ones who strongly agreed, disagreed, and strongly disagreed with this item, $c^{2}(3, N=93)=31.08, p<.05$. 
Table 7

Result of the descriptive statistics, percentage and Chi-square of the teachers' responses related to phonology

\begin{tabular}{|c|c|c|c|c|c|c|c|c|c|}
\hline & \multirow[b]{2}{*}{$N$} & \multirow[b]{2}{*}{ Mean } & \multirow[b]{2}{*}{$\begin{array}{l}\text { Std. } \\
\text { Deviation }\end{array}$} & \multicolumn{4}{|c|}{ Percentage } & \multirow{2}{*}{$\begin{array}{l}\text { Chi- } \\
\text { squar df } \\
\text { e }\end{array}$} & \multirow{2}{*}{$\begin{array}{l}\text { Asym } \\
\text { p. Sig }\end{array}$} \\
\hline & & & & $\begin{array}{l}\text { S. } \\
\text { Agr. }\end{array}$ & Agr & $\begin{array}{l}\text { D.A } \\
\text { gr }\end{array}$ & $\begin{array}{l}\text { S. D. } \\
\text { Agr }\end{array}$ & & \\
\hline $\begin{array}{l}\text { 13. Pronunciation is built through different types } \\
\text { of activities, such as listening, dialogue } \\
\text { practice etc. }\end{array}$ & 20 & 2.75 & .55 & 5 & 65 & 30 & 0 & 10.902 & .00 \\
\hline $\begin{array}{c}\text { 14. There is an adequate amount of pronunciation } \\
\text { practice. }\end{array}$ & 20 & 2.40 & .50 & 0 & 40 & 60 & 0 & .801 & .37 \\
\hline
\end{tabular}

As shown in table 7 , in item $13,5 \%$ of the teachers strongly agreed and $65 \%$ of them agreed that pronunciation is built through different types of activities, such as listening, dialogue practice etc. Moreover, $30 \%$ of the teachers disagreed with this item ( $\mathrm{M}=2.75, \mathrm{SD}=.55$; SUM. of $\mathrm{S}$. Agr. \& Agr. $=70 \%)$. In addition, there is a significant difference between the number of teachers who agreed and the ones who strongly agreed and disagreed with this item, $c^{2}(2, N=20)=10.90$, $p<.05$.

Item 14 considers if there is an adequate amount of pronunciation practice. The findings show that $40 \%$ of the teachers agreed and $60 \%$ of them disagreed that there is an adequate amount of pronunciation practice $(M=2.40, S D=.50)$. Moreover, there is no significant difference between the number of teachers who agreed and the ones who disagreed with this item, $c^{2}(1, N=20)=.80, p>.05$.

Table 8

Result of the descriptive statistics, percentage and Chi-square of the students' responses related to phonology

\begin{tabular}{|c|c|c|c|c|c|c|c|c|c|}
\hline & \multirow[b]{2}{*}{$\mathrm{N}$} & \multirow[b]{2}{*}{ Mean } & \multirow{2}{*}{$\begin{array}{l}\text { Std. } \\
\text { Deviation }\end{array}$} & \multicolumn{4}{|c|}{ Percentage } & \multirow{2}{*}{$\begin{array}{l}\text { Chi- } \\
\text { squar df } \\
\text { e }\end{array}$} & \multirow{2}{*}{$\begin{array}{l}\text { Asym } \\
\text { p. Sig. }\end{array}$} \\
\hline & & & & $\begin{array}{l}\text { S. } \\
\text { Agr. }\end{array}$ & Agr & $\begin{array}{l}\text { D.A } \\
\text { gr }\end{array}$ & $\begin{array}{l}\text { S. D. } \\
\text { Agr }\end{array}$ & & \\
\hline $\begin{array}{l}\text { 13. Pronunciation is built through different types } \\
\text { of activities, such as listening, dialogue } \\
\text { practice etc. }\end{array}$ & 91 & 3.16 & .78 & 36.2 & $\begin{array}{c}47 . \\
3\end{array}$ & $\begin{array}{c}13 . \\
2\end{array}$ & 3.3 & 44.863 & .00 \\
\hline $\begin{array}{l}\text { 14. There is an adequate amount of pronunciation } \\
\text { practice. }\end{array}$ & 92 & 2.37 & .92 & 17.4 & $\begin{array}{c}15 . \\
2\end{array}$ & $\begin{array}{c}54 . \\
3\end{array}$ & 13.1 & 42.603 & .00 \\
\hline
\end{tabular}

Table 8 shows that in item 13,36.2\% of the students strongly agreed and $47.3 \%$ of them agreed that pronunciation is built through different types of activities, such as listening, dialogue practice etc. In addition, $13.2 \%$ of the students disagreed and $3.3 \%$ of them strongly disagreed with this item (M=3.16, SD=.78; SUM. of S. Agr. \& Agr. = 83.5\%). Moreover, there is a significant difference between the number of students who agreed and the ones who strongly agreed, disagreed, and strongly disagreed with this item, $c^{2}(3, N=91)=44.86, p<.05$.

Item 14 considers if there is an adequate amount of pronunciation practice. The results show that $17.4 \%$ of the students strongly agreed and $15.2 \%$ of them agreed that there is an adequate amount of pronunciation practice. In addition, $54.3 \%$ of the students disagreed and $13.1 \%$ of them strongly disagreed with this item $(\mathrm{M}=2.37, \mathrm{SD}=.92$; SUM. of $\mathrm{D}$. Agr. \& S. D. Agr. $=67.4 \%$ ). Moreover, there is a significant difference between the number of students who disagreed and the ones who strongly agreed, agreed, and strongly disagreed with this item, $c^{2}(3, N=92)=42.60, \quad p<.05$. 
Table 9

Result of the descriptive statistics, percentage and Chi-square of the teachers' responses related to language skills



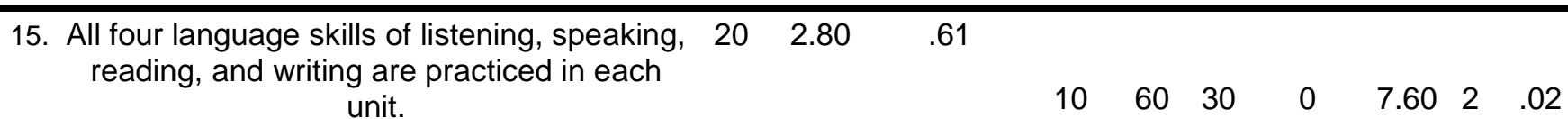

16. The CB uses authentic material at an $20 \quad 2.65$ appropriate level.
17. The CB uses authentic listening material at an 19 appropriate level.

.67

$\begin{array}{lllllll}5 & 60 & 30 & 5 & 16.40 & 3 & .00\end{array}$

2.63

.59

5.352 .42$.

$\begin{array}{cc}\text { 52. } & 42 . \\ 6 & 1\end{array}$

As it is indicated in table 9, in the fifteenth item, $10 \%$ of the teachers strongly agreed and $60 \%$ of them agreed that all four language skills of listening, speaking, reading, and writing are practiced in each unit. Moreover, $30 \%$ of the teachers had the opposite idea and disagreed with the item (M = 2.80, SD=.61; SUM. of S. Agr. \& Agr. $=70 \%)$. In addition, there is a significant difference between the number of teachers who agreed and the ones who strongly agreed and disagreed with this item, $c^{2}(2, N=20)=7.60, p<.05$.

In item $16,5 \%$ of the teachers strongly agreed and $60 \%$ of them agreed that Total English coursebook uses authentic material at an appropriate level. Moreover, $30 \%$ of the teachers disagreed and $5 \%$ of them strongly disagreed with the item ( $M=2.65, \mathrm{SD}=.67$; SUM. of S. Agr. \& Agr. $=65 \%$ ). In addition, there is a significant difference between the number of teachers who agreed and the ones who strongly agreed, disagreed and strongly disagreed with this item, $c^{2}(3, N=$ 20) $=16.40, p<.05$

Item 17 considers if the Total English coursebook uses authentic listening material at an appropriate level. Data analysis shows that $5.3 \%$ of the teachers strongly agreed and $52.6 \%$ of them agreed that the coursebook uses authentic listening material at an appropriate level. Moreover, $42.1 \%$ of the teachers disagreed with this item $(\mathrm{M}=2.63, \mathrm{SD}=.59$; SUM. of $\mathrm{S}$. Agr. \& Agr. $=57.9 \%$ ). In addition, there is a significant difference between the number of teachers who agreed and the ones who strongly agreed and disagreed with this item, $c^{2}(2, N=19)=7.05, p<.05$.

Table 10

Result of the descriptive statistics, percentage and Chi-square of the students' responses related to language skills

\begin{tabular}{|c|c|c|c|c|c|c|c|c|c|}
\hline & \multirow[b]{2}{*}{$\mathrm{N}$} & \multirow[b]{2}{*}{ Mean } & \multirow[b]{2}{*}{$\begin{array}{l}\text { Std. } \\
\text { Deviation }\end{array}$} & \multicolumn{4}{|c|}{ Percentage } & \multirow{2}{*}{$\begin{array}{l}\text { Chi- } \\
\text { ᄀsquar df } \\
\text { e }\end{array}$} & \multirow[b]{2}{*}{$\begin{array}{l}\text { Asym } \\
\text { p. Sig }\end{array}$} \\
\hline & & & & $\begin{array}{l}\text { S. } \\
\text { Agr. }\end{array}$ & Agr & $\begin{array}{l}\text { D.A } \\
\text { gr }\end{array}$ & $\begin{array}{l}\text { S. D. } \\
\text { Agr }\end{array}$ & & \\
\hline $\begin{array}{l}\text { 15. All four language skills of listening, speaking, } \\
\text { reading, and writing are practiced in each } \\
\text { unit. }\end{array}$ & 92 & 2.76 & .87 & 21.7 & $\begin{array}{c}39 . \\
1\end{array}$ & $\begin{array}{c}32 . \\
6\end{array}$ & 6.6 & 22.433 & .00 \\
\hline $\begin{array}{l}\text { 16. The CB uses authentic material at an } \\
\text { appropriate level. }\end{array}$ & 93 & 2.88 & .70 & 18.3 & $\begin{array}{c}52 . \\
6\end{array}$ & 28 & 1.1 & 51.813 & .00 \\
\hline $\begin{array}{c}\text { 17. The CB uses authentic listening material at an } \\
\text { appropriate level. }\end{array}$ & 93 & 2.91 & .67 & 18.3 & $\begin{array}{c}54 . \\
8\end{array}$ & $\begin{array}{c}26 . \\
9\end{array}$ & 0 & 20.382 & .00 \\
\hline
\end{tabular}


As it is shown in Table 10, in item 15, $21.7 \%$ of the students strongly agreed and $39.1 \%$ of them agreed that all four language skills of listening, speaking, reading, and writing are practiced in each unit. In addition, $32.6 \%$ of the students disagreed and $6.6 \%$ of them strongly disagreed with this item ( $\mathrm{M}=2.76, \mathrm{SD}=.87$; SUM. of S. Agr. \& Agr. $=60.8 \%)$. Moreover, there is a significant difference between the number of students who agreed and the ones who strongly agreed, disagreed, and strongly disagreed with this item, $\mathrm{c}^{2}(3, \mathrm{~N}=92)=22.43, \mathrm{p}<.05$.

In Item 16, $18.3 \%$ of the students strongly agreed and $52.6 \%$ of them agreed that Total English coursebook uses authentic material at an appropriate level. In addition, $28 \%$ of the students disagreed and $1.1 \%$ of them strongly disagreed with this item $(\mathrm{M}=2.88, \mathrm{SD}=.70$; SUM. of $\mathrm{S}$. Agr. \& Agr. $=70.9 \%)$. Moreover, there is a significant difference between the number of students who agreed and the ones who strongly agreed, disagreed, and strongly disagreed with this item, $c^{2}(3, N=93)=15.81, p<.05$.

Item 17 considers if the coursebook uses authentic listening material at an appropriate level. The results indicate that $18.3 \%$ of the students strongly agreed and $54.8 \%$ of them agreed that Total English coursebook uses authentic listening material at an appropriate level. In addition, $26.9 \%$ of the students disagreed with this item $(\mathrm{M}=2.91, \mathrm{SD}=.67 ; \mathrm{SUM}$. of $\mathrm{S}$. Agr. \& Agr. $=73.1 \%$ ). Moreover, there is a significant difference between the number of students who agreed and the ones who strongly agreed, disagreed, and strongly disagreed with this item, $c^{2}(3, N=93)=20.38, p<.05$.

As shown in table 11, in item 18, $5 \%$ of the teachers strongly agreed and $75 \%$ of them agreed that Total English coursebook units are related to student needs. Moreover, $15 \%$ of the teachers disagreed and $5 \%$ of them strongly disagreed with this item $(\mathrm{M}=2.80, \mathrm{SD}=.61$; SUM. of $\mathrm{S}$. Agr. \& Agr. $=80 \%)$. In addition, there is a significant difference

\section{Table 11}

Result of the descriptive statistics, percentage and Chi-square of the teachers' responses related to methodology

\begin{tabular}{|c|c|c|c|c|c|c|c|c|c|c|}
\hline & \multirow[b]{2}{*}{$\mathrm{N}$} & \multirow[b]{2}{*}{ Mean } & \multirow[b]{2}{*}{$\begin{array}{l}\text { Std. } \\
\text { Deviation }\end{array}$} & \multicolumn{4}{|c|}{ Percentage } & \multirow{2}{*}{$\begin{array}{c}\text { Chi- } \\
\text { squar } \\
\text { e }\end{array}$} & \multirow[b]{2}{*}{ df } & \multirow[b]{2}{*}{$\begin{array}{l}\text { Asymp. } \\
\text { Sig. }\end{array}$} \\
\hline & & & & S. Agr. & Agr. & $\begin{array}{c}\text { D.A } \\
\text { gr }\end{array}$ & $\begin{array}{c}\text { S. D. } \\
\text { Agr }\end{array}$ & & & \\
\hline 18. The CB units are related to student needs. & 20 & 2.80 & .61 & 5 & 75 & 15 & 5 & 27.20 & 3 & .00 \\
\hline $\begin{array}{l}\text { 19. The CB encourages inductive approach to } \\
\text { learning. }\end{array}$ & 20 & 2.10 & .30 & 0 & 10 & 90 & 0 & 12.80 & 1 & .00 \\
\hline 20. Accuracy is balanced with fluency. & 20 & 2.80 & .61 & 10 & 60 & 30 & 0 & 7.60 & 2 & .00 \\
\hline
\end{tabular}

between the number of teachers who agreed and the ones who strongly agreed, disagreed and strongly disagreed with this item, $c^{2}(3, N=20)=27.20, p<.05$. 
Item 19 considers whether Total English coursebook encourages inductive approach to learning or not. The results indicate that $10 \%$ of the teachers agreed and $90 \%$ of them disagreed that the coursebook encourages inductive approach to learning $(\mathrm{M}=2.10, \mathrm{SD}=.30)$. In addition, there is a significant difference between the number of teachers who disagreed and the ones who agreed with this item, $c^{2}(1, N=20)=12.80, p<.05$.

Table 12

Result of the descriptive statistics, percentage and Chi-square of the students' responses related to methodology

\begin{tabular}{|c|c|c|c|c|c|c|c|c|c|c|}
\hline & \multirow[b]{2}{*}{$\mathrm{N}$} & \multirow[b]{2}{*}{ Mean } & \multirow[b]{2}{*}{$\begin{array}{l}\text { Std. } \\
\text { Deviation }\end{array}$} & \multicolumn{4}{|c|}{ Percentage } & \multirow[b]{2}{*}{$\begin{array}{l}\text { Chi- } \\
\text { square }\end{array}$} & & \multirow[b]{2}{*}{$\begin{array}{l}\text { Asymp. } \\
\text { Sig. }\end{array}$} \\
\hline & & & & S. Agr. & Agr. & $\begin{array}{c}\text { D.A } \\
g r\end{array}$ & $\begin{array}{l}\text { S. D. } \\
\text { Agr }\end{array}$ & & & \\
\hline 18. The CB units are related to student needs. & 92 & 2.91 & .56 & 9.8 & 73.9 & 14.1 & 2.2 & 120.08 & 3 & .00 \\
\hline $\begin{array}{l}\text { 19. The CB encourages inductive approach to } \\
\text { learning. }\end{array}$ & 93 & 2.84 & .58 & 8.6 & 69.9 & 19.3 & 2.2 & 105.58 & 3 & .00 \\
\hline 20. Accuracy is balanced with fluency. & 93 & 2.87 & .67 & 12.9 & 65.6 & 17.2 & 4.3 & 84.93 & 3 & .00 \\
\hline
\end{tabular}

In the last item of this category, $10 \%$ of the teachers strongly agreed and $60 \%$ of them agreed that accuracy is balanced with fluency. In addition, $30 \%$ of the teachers disagreed with this item ( $\mathrm{M}=2.80, \mathrm{SD}=.61$; SUM. of S. Agr. \& Agr. $=70 \%)$. Moreover, there is a significant difference between the number of teachers who agreed and the ones who strongly agreed and disagreed with this item, $\mathrm{c}^{2}(2, \mathrm{~N}=20)=7.60, \mathrm{p}<.05$.

As displayed in table 12 , in item $18,9.8 \%$ of the students strongly agreed and $73.9 \%$ of them agreed that Total English coursebook units are related to student needs. In addition, $14.1 \%$ of the students disagreed and $2.2 \%$ of them strongly disagreed with this item $(\mathrm{M}=2.91, \mathrm{SD}=.56$; SUM. of $\mathrm{S}$. Agr. \& Agr. $=83.7 \%)$. Moreover, there is a significant difference between the number of students who disagreed and the ones who strongly agreed, agreed, and strongly disagreed with this item, $c^{2}(3, N=92)=120.08, p<.05$.

Item 19 considers whether the coursebook encourages inductive approach to learning or not. The results indicate that $8.6 \%$ of the students strongly agreed and $69.9 \%$ of them agreed that Total English coursebook encourages inductive approach to learning. In addition, $19.3 \%$ of the students disagreed and $2.2 \%$ of them strongly disagreed with this item $(\mathrm{M}=2.84, \mathrm{SD}=.58$; SUM. of S. Agr. \& Agr. = 78.5\%). Moreover, there is a significant difference between the number of students who disagreed and the ones who strongly agreed, agreed, and strongly disagreed with this item, $c^{2}(3, N=$ 93) $=105.58, \mathrm{p}<.05$.

In item $20,12.9 \%$ of the students strongly agreed and $65.6 \%$ of them agreed that accuracy is balanced with fluency. In addition, $17.2 \%$ of the students disagreed and $4.3 \%$ of them strongly disagreed with this item $(M=2.87, S D=.67 ; S U M$. of S. Agr. \& Agr. $=78.5 \%$ ). Moreover, there is a significant difference between the number of students who disagreed and the ones who strongly agreed, agreed, and strongly disagreed with this item, $c^{2}(3, N=93)=84.93, p<.05$. 
Table 13

Result of the descriptive statistics, percentage and Chi-square of the teachers' responses related to study skills

\begin{tabular}{|c|c|c|c|c|c|c|c|c|c|c|}
\hline & \multirow{2}{*}{$\mathrm{N}$} & \multirow{2}{*}{ Mean } & \multirow{2}{*}{$\begin{array}{l}\text { Std. } \\
\text { Deviation }\end{array}$} & \multicolumn{4}{|c|}{ Percentage } & \multirow{2}{*}{$\begin{array}{l}\text { Chi- } \\
\text { squar } \\
\text { e }\end{array}$} & & \multirow{2}{*}{$\begin{array}{l}\text { Asymp. } \\
\text { Sig. }\end{array}$} \\
\hline & & & & S. Agr. & Agr. & $\begin{array}{c}\text { D.A } \\
\text { gr }\end{array}$ & $\begin{array}{l}\text { S. D. } \\
\text { Agr }\end{array}$ & & & \\
\hline $\begin{array}{l}\text { 21. The CB includes lessons that reflect on study } \\
\text { techniques such as vocabulary learning } \\
\text { techniques }\end{array}$ & 20 & 2.90 & .64 & 15 & 60 & 25 & 0 & 6.70 & 2 & .03 \\
\hline $\begin{array}{l}\text { 22. The CB contains advice on study skills } \\
\text { development. }\end{array}$ & 20 & 2.70 & .47 & 0 & 70 & 30 & 0 & 3.20 & 1 & .07 \\
\hline $\begin{array}{l}\text { 23. Students are encouraged to take some degree of } \\
\text { responsibility for their learning. }\end{array}$ & 20 & 2.75 & .71 & 15 & 45 & 40 & 0 & 3.10 & 2 & .21 \\
\hline $\begin{array}{l}\text { 24. There are some materials for independent work in } \\
\text { each unit. }\end{array}$ & 18 & 2.66 & .48 & 0 & 66.7 & 33.3 & 0 & 2.00 & 1 & .16 \\
\hline
\end{tabular}

Table 13 indicates that in item 21, 15\% of the teachers strongly agreed and $60 \%$ of them agreed that Total English coursebook includes lessons that reflect on study techniques such as vocabulary learning techniques. Moreover, $25 \%$ of the teachers disagreed with this item ( $\mathrm{M}=2.90, \mathrm{SD}=.64$; SUM. of $\mathrm{S}$. Agr. \& Agr. $=75 \%)$. In addition, there is a significant difference between the number of teachers who agreed and the ones who strongly agreed and disagreed with this item, $c^{2}(2, N=20)=6.70, p<.05$.

Item 22 considers if Total English coursebook contains advice on study skills development. Data analysis shows that $70 \%$ of the teachers agreed and $30 \%$ of them disagreed that the coursebook contains advice on study skills development ( $\mathrm{M}=$ $2.70, \mathrm{SD}=.47$ ). In addition, there is no significant difference between the number of teachers who agreed and the ones who disagreed with this item, $\mathrm{c}^{2}(1, \mathrm{~N}=20)=3.20, \mathrm{p}<.05$.

In item $23,15 \%$ of the teachers strongly agreed and $45 \%$ of them agreed that students are encouraged to take some degree of responsibility for their learning. Moreover, $40 \%$ of the teachers disagreed with this item $(M=2.75, S D=.71$; SUM. of S. Agr. \& Agr. $=60 \%$ ). In addition, there is no significant difference between the number of teachers who agreed and the ones who strongly agreed and disagreed with this item, $c^{2}(2, N=20)=3.10, p>.05$.

In item $24,66.7 \%$ of the teachers agreed and $33.3 \%$ of them disagreed that there are some materials for independent work in each unit $(\mathrm{M}=2.66, \mathrm{SD}=.48)$. In addition, there is no significant difference between the number of teachers who agreed and the ones who disagreed with this item, $c^{2}(1, N=20)=2.00, p>.05$. 
Table 14

Result of the descriptive statistics, percentage and Chi-square of the students' responses related to study skills

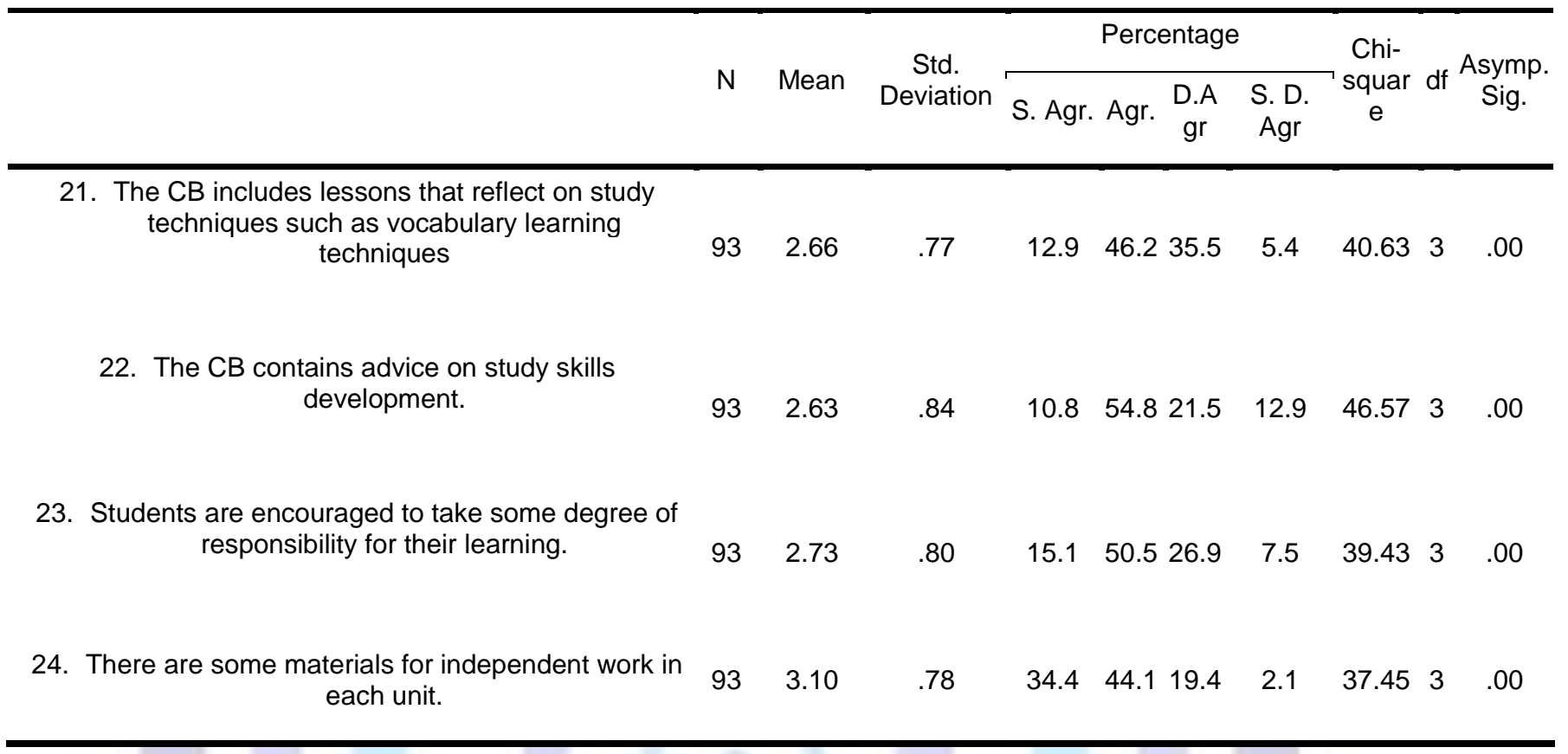

Table 14 shows that in item $21,12.9 \%$ of the students strongly agreed and $46.2 \%$ of them agreed that Total English coursebook includes lessons that reflect on study techniques such as vocabulary learning techniques. In addition, $35.5 \%$ of the students disagreed and $5.4 \%$ of them strongly disagreed with this item $(M=2.66, S D=.77 ; S U M$. of S. Agr. \& Agr. $=59.1 \%)$. Moreover, there is a significant difference between the number of students who agreed and the ones who strongly agreed, disagreed, and strongly disagreed with this item, $c^{2}(3, N=93)=40.63, p<.05$.

Item 22 considers if the coursebook contains advice on study skills development. The results show that $10.8 \%$ of the students strongly agreed and $54.8 \%$ of them agreed that Total English coursebook contains advice on study skills development. In addition, $21.5 \%$ of the students disagreed and $12.9 \%$ of them strongly disagreed with this item (M = 2.63, SD=.84; SUM. of D. Agr. \& S. D. Agr. $=65.6 \%)$. Moreover, there is a significant difference between the number of students who disagreed and the ones who strongly agreed, agreed, and strongly disagreed with this item, $\mathrm{c}^{2}(3, \mathrm{~N}=$ 93) $=46.57, \mathrm{p}<.05$

In item $23,15.1 \%$ of the students strongly agreed and $50.5 \%$ of them agreed that students are encouraged to take some degree of responsibility for their learning. In addition, $26.9 \%$ of the students disagreed and $7.5 \%$ of them strongly disagreed with this item ( $\mathrm{M}=2.73, \mathrm{SD}=.80$; SUM. of S. Agr. \& Agr. $=65.6 \%)$. Moreover, there is a significant difference between the number of students who agreed and the ones who strongly agreed, disagreed, and strongly disagreed with this item, $c^{2}(3, N=93)=39.43, p<.05$.

Item 24 considers whether there are some materials for independent work in each unit or not. The results show that $34.4 \%$ of the students strongly agreed and $44.1 \%$ of them agreed that there are some materials for independent work in each unit. In addition, $19.4 \%$ of the students disagreed and $2.1 \%$ of them strongly disagreed with this item $(M=3.10, S D=.78$; SUM. of S. Agr. \& Agr. = 78.5\%). Moreover, there is a significant difference between the number of students who agreed and the ones who strongly agreed, disagreed, and strongly disagreed with this item, $c^{2}(3, N=93)=37.45, p<.05$. 
Table 15

Result of the descriptive statistics, percentage and Chi-square of the teachers' responses related to visuals

\begin{tabular}{|c|c|c|c|c|c|c|c|c|c|}
\hline & \multirow[b]{2}{*}{$\mathrm{N}$} & \multirow[b]{2}{*}{ Mean } & \multirow[b]{2}{*}{$\begin{array}{c}\text { Std. } \\
\text { Deviation }\end{array}$} & \multicolumn{4}{|c|}{ Percentage } & \multirow{2}{*}{$\begin{array}{l}\text { Chi- } \\
\text { squar df } \\
\text { e }\end{array}$} & \multirow{2}{*}{$\begin{array}{l}\text { Asym } \\
\text { p. Sig. }\end{array}$} \\
\hline & & & & $\begin{array}{l}\text { S. } \\
\text { Agr. }\end{array}$ & Agr & $\begin{array}{l}\text { D.A } \\
\text { gr }\end{array}$ & $\begin{array}{l}\text { S. D. } \\
\text { Agr }\end{array}$ & & \\
\hline 25. The textbook has attractive layout. & 20 & 2.60 & .94 & 10 & 60 & 10 & 20 & 13.603 & .00 \\
\hline $\begin{array}{l}\text { 26. The font size and type used in the book are } \\
\text { appropriate. }\end{array}$ & 19 & 3.10 & .65 & 26.3 & $\begin{array}{c}57 . \\
9\end{array}$ & $\begin{array}{c}15 . \\
8\end{array}$ & 0 & 5.472 & .06 \\
\hline $\begin{array}{l}\text { 27. The visuals are reasonably well produced and } \\
\text { attractive. }\end{array}$ & 20 & 2.70 & .73 & 15 & 40 & 45 & 0 & 3.102 & .21 \\
\hline
\end{tabular}

As demonstrated in table 15, in item 25, $10 \%$ of the teachers strongly agreed and $60 \%$ of them agreed that the textbook has attractive layout. In addition, $10 \%$ of the teachers disagreed and $20 \%$ of them strongly disagreed with this item (M $=2.60, \mathrm{SD}=.94 ; \mathrm{SUM}$. of S. Agr. \& Agr. $=70 \%$ ). Moreover, there is a significant difference between the number of teachers who agreed and the ones who strongly agreed, disagreed, and strongly disagreed with this item, $c^{2}(3, N=20)=$ $13.60, \mathrm{p}<.05$.

In item $26,26.3 \%$ of the teachers strongly agreed and $57.9 \%$ of them agreed that the font size and type used in the book are appropriate. Moreover, $15.8 \%$ of the teachers disagreed with this item (M = 3.10, SD=.65; SUM. of S. Agr. \& Agr. $=84.2 \%$ ). In addition, there is no significant difference between the number of teachers who agreed and the ones who strongly agreed and disagreed with this item, $c^{2}(2, N=19)=5.47, p>.05$.

The 27 th item considers if the visuals are reasonably well produced and attractive. The results indicate that $15 \%$ of the teachers strongly agreed and $40 \%$ of them agreed that the visuals are reasonably well produced and attractive. Moreover, $45 \%$ of the teachers disagreed with this item ( $\mathrm{M}=2.70, \mathrm{SD}=.73$; SUM. of S. Agr. \& Agr. $=55 \%)$. In addition,

Table 16

Result of the descriptive statistics, percentage and Chi-square of the students' responses related to visuals

\begin{tabular}{|c|c|c|c|c|c|c|c|c|c|}
\hline & \multirow[b]{2}{*}{$\mathrm{N}$} & \multirow[b]{2}{*}{ Mean } & \multirow[b]{2}{*}{$\begin{array}{l}\text { Std. } \\
\text { Deviation }\end{array}$} & \multicolumn{4}{|c|}{ Percentage } & \multirow{2}{*}{$\begin{array}{l}\text { Chi- } \\
\text { squar df } \\
\text { e }\end{array}$} & \multirow[b]{2}{*}{$\begin{array}{l}\text { Asym } \\
\text { p. Sig. }\end{array}$} \\
\hline & & & & $\begin{array}{l}\text { S. } \\
\text { Agr. }\end{array}$ & Agr & $\begin{array}{l}\text { D.A } \\
\text { gr }\end{array}$ & $\begin{array}{l}\text { S. D. } \\
\text { Agr }\end{array}$ & & \\
\hline 25. The textbook has attractive layout. & 93 & 2.79 & .85 & 18.3 & $\begin{array}{c}41 . \\
9\end{array}$ & $\begin{array}{c}32 . \\
3\end{array}$ & 7.5 & 25.663 & .00 \\
\hline $\begin{array}{l}\text { 26. The font size and type used in the book are } \\
\text { appropriate. }\end{array}$ & 93 & 3.20 & .66 & 34.4 & $\begin{array}{c}51 . \\
6\end{array}$ & 14 & & 19.802 & .00 \\
\hline $\begin{array}{l}\text { 27. The visuals are reasonably well produced } \\
\text { and attractive. }\end{array}$ & 93 & 2.65 & .96 & 22.6 & $\begin{array}{c}32 . \\
3\end{array}$ & $\begin{array}{c}33 . \\
3\end{array}$ & 11.8 & 11.213 & .01 \\
\hline
\end{tabular}

there is no significant difference between the number of teachers who agreed and the ones who strongly agreed and disagreed with this item, $c^{2}(2, N=20)=3.10, p>.05$.

As it is indicated in table 16 , in item $25,18.3 \%$ of the students strongly agreed and $41.9 \%$ of them agreed that the textbook has attractive layout. In addition, $32.3 \%$ of the students disagreed and $7.5 \%$ of them strongly disagreed with this item (M = 2.79, SD=.85; SUM. of S. Agr. \& Agr. = 60.2\%). Moreover, there is a significant difference between the number of students who agreed and the ones who strongly agreed, disagreed, and strongly disagreed with this item, $c^{2}(3, N=93)=25.66, p<.05$. Item 26 considers whether the font size and type used in the book are appropriate or not. The results indicate that $34.4 \%$ of the students strongly agreed and $51.6 \%$ of them agreed that the font size and type used in the book are appropriate. In addition, $14 \%$ of the students disagreed with this item $(\mathrm{M}=3.20, \mathrm{SD}=.66$; SUM. of $\mathrm{S}$. Agr. \& Agr. $=86 \%$ ). Moreover, there is a significant difference between the number of students who agreed and the ones who strongly agreed and disagreed with this item, $c^{2}(3, N=93)=19.80, p<.05$. 
In item 27, $22.6 \%$ of the students strongly agreed and $32.3 \%$ of them agreed that the visuals are reasonably well produced and attractive. In addition, $33.3 \%$ of the students disagreed and $11.8 \%$ of them strongly disagreed with this item $(\mathrm{M}=2.65, \mathrm{SD}=.96$; SUM. of $\mathrm{S}$. Agr. \& Agr. = 54.9\%). Moreover, there is a significant difference between the number of students who disagreed and the ones who strongly agreed, agreed, and strongly disagreed with this item, $c^{2}(3, N$ $=93)=11.21, p<.05$.

Table 17

Result of the descriptive statistics, percentage and Chi-square of the teachers' responses related to practice and testing

\begin{tabular}{|c|c|c|c|c|c|c|c|c|c|c|}
\hline & \multirow[b]{2}{*}{$\mathrm{N}$} & \multirow[b]{2}{*}{ Mean } & \multirow[b]{2}{*}{$\begin{array}{c}\text { Std. } \\
\text { Deviation }\end{array}$} & \multicolumn{4}{|c|}{ Percentage } & \multirow{2}{*}{\multicolumn{2}{|c|}{$\begin{array}{l}\text { Chi- } \\
\text { squar d } \\
\text { e }\end{array}$}} & \multirow{2}{*}{$\begin{array}{l}\text { Asym } \\
\text { p. Sig. }\end{array}$} \\
\hline & & & & $\begin{array}{l}\text { S. } \\
\text { Agr. }\end{array}$ & Agr & $\begin{array}{l}\text { D.A } \\
\text { gr }\end{array}$ & $\begin{array}{l}\text { S. D. } \\
\text { Agr }\end{array}$ & & & \\
\hline $\begin{array}{l}\text { 28. The CB provides communicative exercises } \\
\text { that enable learners to carry out their } \\
\text { communicative tasks in real-life situations. }\end{array}$ & 20 & 2.80 & .83 & 15 & 60 & 15 & 10 & 13.20 & 3 & .00 \\
\hline $\begin{array}{l}\text { 29. There are directions to explain how every } \\
\text { exercise can be done. }\end{array}$ & 20 & 2.85 & .36 & 0 & 85 & 15 & 0 & 9.80 & 1 & .00 \\
\hline 30. The number of exercises is suitable. & 20 & 2.50 & .51 & 0 & 55 & 45 & 0 & .20 & 1 & .65 \\
\hline $\begin{array}{l}\text { 31. The textbook provides appropriate periodical } \\
\text { tests for diagnostic purposes. }\end{array}$ & 20 & 2.80 & .61 & 10 & 60 & 30 & 0 & 7.60 & 2 & .02 \\
\hline
\end{tabular}

As shown in table 17, in item 28, $15 \%$ of the teachers strongly agreed and $60 \%$ of them agreed that Total English coursebook provides communicative exercises that enable learners to carry out their communicative tasks in real-life situations. Moreover, $15 \%$ of the teachers disagreed and $10 \%$ of them strongly disagreed with this item ( $\mathrm{M}=2.80$, $\mathrm{SD}=.83$; SUM. of S. Agr. \& Agr. $=75 \%$ ). In addition, there is a significant difference between the number of teachers who agreed and the ones who strongly agreed, disagreed and strongly disagreed with this item, $c^{2}(3, N=20)=13.20, p<$ .05 .

In item $29,85 \%$ of the teachers agreed and $15 \%$ of them disagreed that there are directions to explain how every exercise can be done $(\mathrm{M}=2.85, \mathrm{SD}=.59)$. In addition, there is a significant difference between the number of teachers who agreed and the ones who disagreed with this item, $c^{2}(1, N=20)=9.80, p<.05$.

In item $30,55 \%$ of the teachers agreed and $45 \%$ of them disagreed that the number of exercises is suitable $(\mathrm{M}=2.84$, $\mathrm{SD}=.69$ ). In addition, there is no significant difference between the number of teachers who agreed and the ones who disagreed with this item, $c^{2}(1, N=20)=.20, p>.05$.

In item $31,10 \%$ of the teachers strongly agreed and $60 \%$ of them agreed that the textbook provides appropriate periodical tests for diagnostic purposes. Moreover, $30 \%$ of the teachers disagreed with this item (M $=2.80, S D=.61$; $S U M$. of S. Agr. \& Agr. $=70 \%$ ). In addition, there is a significant difference between the number of teachers who agreed and the ones who strongly agreed and disagreed with this item, $c^{2}(2, N=20)=7.60, p<.05$. 
Table 19

Result of the descriptive statistics, percentage and Chi-square of the teachers' responses related to supplementary material

\begin{tabular}{|c|c|c|c|c|c|c|c|c|c|}
\hline & \multirow[b]{2}{*}{$\mathrm{N}$} & \multirow[b]{2}{*}{ Mean } & \multirow{2}{*}{$\begin{array}{l}\text { Std. } \\
\text { Deviatio } \\
n\end{array}$} & \multicolumn{4}{|c|}{ Percentage } & \multirow{2}{*}{$\begin{array}{l}\text { Chi- } \\
\text { squar df } \\
\text { e }\end{array}$} & \multirow{2}{*}{$\begin{array}{l}\text { Asym } \\
\text { p. Sig. }\end{array}$} \\
\hline & & & & $\begin{array}{l}\text { S. } \\
\text { Agr. }\end{array}$ & Agr & $\begin{array}{l}\text { D.A } \\
\text { gr }\end{array}$ & $\begin{array}{l}\text { S. D. } \\
\text { Agr }\end{array}$ & & \\
\hline $\begin{array}{l}\text { 32. The supplementary material such as posters } \\
\text { and flash cards, etc. accompanying the book is } \\
\text { attractive and suitable. }\end{array}$ & 20 & 2.45 & .51 & 0 & 45 & 55 & & .201 & .65 \\
\hline & & & & & & & 0 & & \\
\hline $\begin{array}{l}\text { 33. There is an appropriate teacher's guide to aid } \\
\text { the teacher. }\end{array}$ & 20 & 2.65 & .74 & 5 & 65 & 20 & 10 & 18.003 & .00 \\
\hline
\end{tabular}

As displayed in table 19 , in item $32,45 \%$ of the teachers agreed and $55 \%$ of them disagreed that the supplementary material such as posters and flash cards, etc. accompanying the book is attractive and suitable $(M=2.22, S D=1.00)$. Moreover, there is no significant difference between the number of teachers who disagreed and the ones who agreed with this item, $c^{2}(1, N=20)=.20, p>.05$.

In item $33,5 \%$ of the teachers strongly agreed and $65 \%$ of them agreed that there is an appropriate teacher's guide to aid the teacher. Moreover, $20 \%$ of the teachers disagreed and $10 \%$ of them strongly disagreed with this item $(\mathrm{M}=2.65$, $\mathrm{SD}=.74$; SUM. of S. Agr. \& Agr. $=70 \%$ ). In addition, there is a significant difference between the number of teachers who agreed and the ones who strongly agreed, disagreed and strongly disagreed with this item, $c^{2}(3, N=20)=18.00, p<$ .05 .

Table 20

Result of the descriptive statistics, percentage and Chi-square of the teachers' responses related to objectives

\begin{tabular}{|c|c|c|c|c|c|c|c|c|c|}
\hline & \multirow[b]{2}{*}{$N$} & \multirow[b]{2}{*}{ Mean } & \multirow[b]{2}{*}{$\begin{array}{l}\text { Std. } \\
\text { Deviation }\end{array}$} & \multicolumn{4}{|c|}{ Percentage } & \multirow{2}{*}{$\begin{array}{l}\text { Chi- } \\
\text { squar df } \\
\text { e }\end{array}$} & \multirow{2}{*}{$\begin{array}{l}\text { Asym } \\
\text { p. Sig. }\end{array}$} \\
\hline & & & & $\begin{array}{l}\text { S. } \\
\text { Agr. }\end{array}$ & Agr & $\begin{array}{l}\text { D.A } \\
\text { gr }\end{array}$ & $\begin{array}{l}\text { S. D. } \\
\text { Agr }\end{array}$ & & \\
\hline \multirow{2}{*}{$\begin{array}{l}\text { 34. The terminal goals are specified in the } \\
\text { Teacher's Manual or the student's Book. }\end{array}$} & 20 & 2.70 & .57 & & & & & & \\
\hline & & & & 5 & 60 & 35 & 0 & 9.102 & .01 \\
\hline \multirow{2}{*}{$\begin{array}{l}\text { 35. The developmental objectives are specified at } \\
\text { the beginning of each lesson. }\end{array}$} & 20 & 2.85 & .36 & & & & & & \\
\hline & & & & 0 & 85 & 15 & 0 & 9.801 & .00 \\
\hline \multirow{2}{*}{$\begin{array}{l}\text { 36. Developmental objectives meet the needs of } \\
\text { learners. }\end{array}$} & 20 & 3.05 & .22 & & & & & & \\
\hline & & & & 5 & 95 & 0 & 0 & 16.201 & .00 \\
\hline \multirow{2}{*}{$\begin{array}{l}\text { 37. Developmental objectives suit the level of the } \\
\text { learners. }\end{array}$} & 20 & 2.65 & .74 & & & & & & \\
\hline & & & & 5 & 65 & 20 & 10 & 18.003 & .00 \\
\hline
\end{tabular}


Table 20 shows that in item 34, 5\% of the teachers strongly agreed and $60 \%$ of them agreed that the terminal goals are specified in the Teacher's Manual or the student's Book. Moreover, $35 \%$ of the teachers disagreed with this item ( $\mathrm{M}=$ 2.70, SD=.57; SUM. of S. Agr. \& Agr. $=65 \%$ ). In addition, there is a significant difference between the number of teachers who agreed and the ones who strongly agreed and disagreed with this item, $c^{2}(2, N=20)=9.10, p<.05$.

Item 35 considers if the developmental objectives are specified at the beginning of each lesson. The results indicate that $85 \%$ of the teachers agreed and $15 \%$ of them disagreed that the developmental objectives are specified at the beginning of each lesson $(\mathrm{M}=2.85, \mathrm{SD}=.36)$. In addition, there is a significant difference between the number of teachers who agreed and the ones who disagreed with this item, $\mathrm{c}^{2}(1, \mathrm{~N}=20)=9.80, \mathrm{p}<.05$.

In item $36,5 \%$ of the teachers strongly agreed and $95 \%$ of them agreed that developmental objectives meet the needs of learners $(M=3.05, S D=.22$; SUM. of $S$. Agr. \& Agr. $=100 \%)$. In addition, there is a significant difference between the number of teachers who agreed and the ones who strongly agreed with this item, $c^{2}(1, N=20)=16.20, p<.05$.

In the last item of this category, $5 \%$ of the teachers strongly agreed and $65 \%$ of them agreed that developmental objectives suit the level of the learners. Moreover, $20 \%$ of the teachers disagreed and $10 \%$ of them strongly disagreed with this item (M = 2.65, SD=.74; SUM. of S. Agr. \& Agr. $=70 \%$ ). Moreover, there is a significant difference between the number of teachers who agreed and the ones who strongly agreed, disagreed and strongly disagreed with this item, $c^{2}(3, N=20)=18.00, p<.05$.

\section{Table 21}

Result of the descriptive statistics, percentage and Chi-square of the teachers' responses related to content selection

\begin{tabular}{|c|c|c|c|c|c|c|c|c|c|}
\hline & \multirow[b]{2}{*}{$N$} & \multirow[b]{2}{*}{ Mean } & \multirow{2}{*}{$\begin{array}{c}\text { Std. } \\
\text { Deviation }\end{array}$} & \multicolumn{4}{|c|}{ Percentage } & \multirow{2}{*}{$\begin{array}{l}\text { Chi- } \\
\text { squar df } \\
\text { e }\end{array}$} & \multirow{2}{*}{$\begin{array}{l}\text { Asym } \\
\text { p. Sig }\end{array}$} \\
\hline & & & & $\begin{array}{l}\text { S. } \\
\text { Agr. }\end{array}$ & Agr & $\begin{array}{l}\text { D.A } \\
\text { gr }\end{array}$ & $\begin{array}{l}\text { S. D. } \\
\text { Agr }\end{array}$ & & \\
\hline $\begin{array}{l}\text { 38. Content selection reflects the objectives of } \\
\text { the course. }\end{array}$ & 20 & 2.95 & .39 & 5 & 85 & 10 & 0 & 24.102 & .00 \\
\hline $\begin{array}{l}\text { 39. Content selection suits the level of the } \\
\text { course. }\end{array}$ & 20 & 3.05 & .51 & 15 & 75 & 10 & 0 & 15.702 & .00 \\
\hline $\begin{array}{l}\text { 40. Content selection suits the time limit allowed } \\
\text { for the course. }\end{array}$ & 20 & 2.55 & .51 & 0 & 55 & 45 & 0 & .201 & .65 \\
\hline
\end{tabular}

As indicated in table 21 , in item $38,5 \%$ of the teachers strongly agreed and $85 \%$ of them agreed that content selection reflects the objectives of the course. Moreover, $10 \%$ of the teachers disagreed with this item $(\mathrm{M}=2.95, \mathrm{SD}=.39$; SUM. of S. Agr. \& Agr. $=90 \%$ ). In addition, there is a significant difference between the number of teachers who agreed and the ones who strongly agreed and disagreed with this item, $c^{2}(2, N=20)=24.10, p<.05$.

Item 39 considers whether content selection suits the level of the course or not. Data analysis shows that $15 \%$ of the teachers strongly agreed and $75 \%$ of them agreed that content selection suits the level of the course. Moreover, $10 \%$ of the teachers disagreed with this item $(\mathrm{M}=3.05, \mathrm{SD}=.51$; SUM. of $\mathrm{S}$. Agr. \& Agr. $=90 \%)$. In addition, there is a significant difference between the number of teachers who agreed and the ones who strongly agreed and disagreed with this item, $c^{2}(2, N=20)=15.70, p<.05$.

In item $40,55 \%$ of the teachers agreed and $45 \%$ of them disagreed that content selection suits the time limit allowed for the course $(\mathrm{M}=2.55, \mathrm{SD}=.51)$. Moreover, there is no significant difference between the number of teachers who agreed and the ones who disagreed with this item, $c^{2}(1, N=20)=.20, p>.05$. 
Table 22

Result of the descriptive statistics, percentage and Chi-square of the teachers' responses related to gradation

\begin{tabular}{|c|c|c|c|c|c|c|c|c|}
\hline & \multirow[b]{2}{*}{ Mean } & \multirow{2}{*}{$\begin{array}{c}\text { Std. } \\
\text { Deviatio } \\
n\end{array}$} & \multicolumn{4}{|c|}{ Percentage } & \multirow{2}{*}{$\begin{array}{l}\text { Chi- } \\
\text { squar df } \\
\text { e }\end{array}$} & \multirow{2}{*}{$\begin{array}{l}\text { Asym } \\
\text { p. Sig. }\end{array}$} \\
\hline $\mathrm{N}$ & & & $\begin{array}{c}\text { S. } \\
\text { Agr. }\end{array}$ & $\begin{array}{c}\text { Agr } \\
.\end{array}$ & $\begin{array}{c}\text { D.A } \\
\text { gr }\end{array}$ & $\begin{array}{c}\text { S. D. } \\
\text { Agr }\end{array}$ & & \\
\hline 41. The grading of items is suitable for the learners. 20 & 2.70 & .57 & 5 & 60 & 35 & 0 & 9.102 & .01 \\
\hline
\end{tabular}

As demonstrated in table 22, in item 41,5\% of the teachers strongly agreed and $60 \%$ of them agreed that the grading of items is suitable for the learners. Moreover, $35 \%$ of the teachers disagreed with this item $(\mathrm{M}=2.70, \mathrm{SD}=.57 ; \mathrm{SUM}$. of $\mathrm{S}$. Agr. \& Agr. $=65 \%$ ). In addition, there is a significant difference between the number of teachers who agreed and the ones who strongly agreed and disagreed with this item, $c^{2}(2, N=20)=.10, p<.05$.

Table 23

Result of the descriptive statistics, percentage and Chi-square of the teachers' responses related to culture

\begin{tabular}{|c|c|c|c|c|c|c|}
\hline \multirow[b]{2}{*}{$\mathrm{N}$} & \multirow[b]{2}{*}{ Mean } & \multicolumn{4}{|c|}{ Percentage } & \\
\hline & & Deviation & $\begin{array}{l}\text { S. } \\
\text { Agr. }\end{array}$ & $\begin{array}{c}\text { Agr D.A } \\
. \quad \mathrm{gr}\end{array}$ & $\begin{array}{l}\text { S. D. } \\
\text { Agr }\end{array}$ & $\begin{array}{l}\text { squar df } \\
\text { e }\end{array}$ \\
\hline
\end{tabular}

42. The coursebook aims to alienate students $\quad 20 \quad 2.35 \quad .49$ from their

own culture.

$\begin{array}{lllllll}0 & 35 & 65 & 0 & 1.80 & 1 & .18\end{array}$

43. The coursebook is a vehicle to advertise the $20 \quad 2.55$ Anglo-American culture.

.51

$\begin{array}{lllllll}0 & 55 & 45 & 0 & .20 & 1 & .65\end{array}$

44. The illustrations are culturally appropriate to $20 \quad 2.50$ .76 the students.

$\begin{array}{lllllll}5 & 50 & 35 & 10 & 10.80 & 3 & .01\end{array}$

45. It is possible to involve the local culture and $20 \quad 2.90$ .55 language in the textbook.

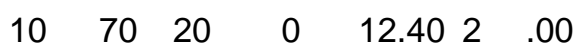

46. The coursebook is in line with promoting the $20 \quad 2.65$ .74 concept of World Englishes (WE).

$\begin{array}{lllllll}5 & 65 & 20 & 10 & 18.00 & 3 & .00\end{array}$

47. Cultural sensitivities have been considered. $\quad \begin{array}{lll}20 & 2.50 & .76\end{array}$ $\begin{array}{lllllll}5 & 50 & 35 & 10 & 10.80 & 3 & .01\end{array}$

48. It takes religious considerations into account. $20 \quad 2.10 \quad 64$ $\begin{array}{lllllll}5 & 10 & 75 & 10 & 26.80 & 3 & .00\end{array}$ 
49. It is free from ideological tendencies. $\quad \begin{array}{lll}20 & 2.80 & .41\end{array}$

50. It raises awareness by avoiding or realizing $20 \quad 2.95$ cultural stereotypes

51. It prepares students to interact with people from other cultures.

52. It aims at international culture

53. The social and cultural contexts in the coursebook are comprehensible to the learners.
$20 \quad 2.95$

.51

$\begin{array}{llllll}0 & 80 & 20 & 0 & 7.20 & 1\end{array}$

.01

2

$\begin{array}{lllll}0 & 95 & 0 & 5 & 28.90\end{array}$

2

$\begin{array}{lllll}0 & 75 & 15 & 0 & 15.70\end{array}$

.00

$\begin{array}{lll}20 & 3.25 & .55\end{array}$

$30 \quad 65 \quad 5 \quad 0 \quad 10.90^{2}$

.00

$\begin{array}{lll}20 & 2.95 & .60\end{array}$

2

As can be seen in table 23, in item 42, 35\% of the teachers agreed and $65 \%$ of them disagreed that Total English coursebook aims to alienate students from their own culture $(M=2.35, S D=1.23)$. Moreover, there is no significant difference between the number of teachers who disagreed and the ones who agreed with this item, $c^{2}(1, N=20)=1.80$, $p>.05$.

Item 43 considers if Total English coursebook is a vehicle to advertise the Anglo-American culture. The results show that $55 \%$ of the teachers agreed and $45 \%$ of them disagreed that the coursebook is a vehicle to advertise the Anglo-American culture $(\mathrm{M}=2.55, \mathrm{SD}=.51)$. Moreover, there is no significant difference between the number of teachers who agreed and the ones who disagreed with this item, $c^{2}(1, N=20)=.20, p>.05$.

In item $44,5 \%$ of the teachers strongly agreed and $50 \%$ of them agreed that the illustrations are culturally appropriate to the students. Moreover, $35 \%$ of the teachers disagreed and $10 \%$ of them strongly disagreed with this item $(\mathrm{M}=2.50$, $\mathrm{SD}=.76$; SUM. of S. Agr. \& Agr. $=55 \%$ ). In addition, there is a significant difference between the number of teachers who agreed and the ones who strongly agreed, disagreed and strongly disagreed with this item, $c^{2}(3, N=20)=10.80, p<$ .05 .

Item 45 considers whether it is possible to involve the local culture and language in the textbook or not. Data analysis indicates that $10 \%$ of the teachers strongly agreed and $70 \%$ of them agreed that it is possible to involve the local culture and language in the textbook. Moreover, $20 \%$ of the teachers disagreed with this item $(\mathrm{M}=2.90, \mathrm{SD}=.55$; $\mathrm{SUM}$. of $\mathrm{S}$. Agr. $\&$ Agr. $=80 \%$ ). In addition, there is a significant difference between the number of teachers who agreed and the ones who strongly agreed and disagreed with this item, $c^{2}(2, N=20)=12.40, p<.05$.

In item $46,5 \%$ of the teachers strongly agreed and $65 \%$ of them agreed that Total English coursebook is in line with promoting the concept of World Englishes (WE). Moreover, $20 \%$ of the teachers disagreed and $10 \%$ of them strongly disagreed with this item ( $\mathrm{M}=2.65, \mathrm{SD}=.74$; SUM. of $\mathrm{S}$. Agr. \& Agr. $=70 \%)$. In addition, there is a significant difference between the number of teachers who agreed and the ones who strongly agreed, disagreed and strongly disagreed with this item, $c^{2}(3, N=20)=18.00, p<.05$.

Item 47 indicates that $5 \%$ of the teachers strongly agreed and $50 \%$ of them agreed that cultural sensitivities have been considered. Moreover, $35 \%$ of the teachers disagreed and $10 \%$ of them strongly disagreed with this item $(\mathrm{M}=2.50$, $\mathrm{SD}=.76$; SUM. of S. Agr. \& Agr. $=55 \%$ ). In addition, there is a significant difference between the number of teachers who agreed and the ones who strongly agreed, disagreed and strongly disagreed with this item, $c^{2}(3, N=20)=10.80, p<$ 05 .

In item $48,5 \%$ of the teachers strongly agreed and $10 \%$ of them agreed that Total English coursebook takes religious considerations into account. Moreover, $75 \%$ of the teachers disagreed and $10 \%$ of them strongly disagreed with this item $(M=2.10, S D=.64$; SUM. of D. Agr. \& S. D. Agr. $=85 \%)$. In addition, there is a significant difference between the number of teachers who disagreed and the ones who strongly agreed, agreed and strongly disagreed with this item, $\mathrm{c}^{2}(3, \mathrm{~N}=20)=26.80, \mathrm{p}<.05$.

Item 49 considers if the coursebook is free from ideological tendencies. The results show that $80 \%$ of the teachers agreed and $20 \%$ of them disagreed that Total English coursebook is free from ideological tendencies $(M=2.95, S D=.83)$. In addition, there is a significant difference between the number of teachers who agreed and the ones who disagreed with this item, $c^{2}(1, N=20)=7.20, p<.05$. 
In item $50,95 \%$ of the teachers agreed and $5 \%$ of them strongly disagreed that the coursebook raises awareness by avoiding or realizing cultural stereotypes $(\mathrm{M}=2.95, \mathrm{SD}=.51)$. In addition, there is a significant difference between the number of teachers who agreed and the ones who strongly disagreed with this item, $c^{2}(1, N=20)=28.90, p<.05$.

Item 51 considers if the coursebook prepares students to interact with people from other cultures. Data analysis shows that $75 \%$ of the teachers agreed and $15 \%$ of them disagreed that Total English coursebook prepares students to interact with people from other cultures $(\mathrm{M}=2.95, \mathrm{SD}=.51)$. In addition, there is a significant difference between the number of teachers who agreed and the ones who disagreed with this item, $c^{2}(1, N=20)=15.70, p<.05$.

In item 52, 30\% of the teachers strongly agreed and $65 \%$ of them agreed that Total English coursebook aims at international culture. Moreover, $5 \%$ of the teachers disagreed with this item (M = 3.25, SD=.55; SUM. of S. Agr. \& Agr. $=95 \%$ ). In addition, there is a significant difference between the number of teachers who agreed and the ones who strongly agreed and disagreed with this item, $c^{2}(2, N=20)=10.90, p<.05$.

The last item of the category, item 53 , indicates that $15 \%$ of the teachers strongly agreed and $65 \%$ of them agreed that the social and cultural contexts in the coursebook are comprehensible to the learners. Moreover, $20 \%$ of the teachers disagreed with this item ( $\mathrm{M}=2.95, \mathrm{SD}=.60$; SUM. of $\mathrm{S}$. Agr. \& Agr. $=80 \%)$. In addition, there is a significant difference between the number of teachers who agreed and the ones who strongly agreed and disagreed with this item, $c^{2}(2, N=$ 20) $=9.10, p<.05$.

\subsection{Analysis of the Interviews}

In order to empower the gathered data, the researcher interviewed 25 percent of the teachers and 10 percent of the students who have participated in this study. The findings of these interviews were employed in extracting strengths and weaknesses of the coursebooks in section 5.2. Moreover, a brief report of the interviewees' comments is presented below.

From the teachers' perspective, Total English is culturally impartial and it puts special emphasis on vocabulary. They also stated that the coursebook consists of familiar topics which encourage learners to speak. However, they asserted that the number of pronunciation practice is not sufficient. Moreover, a few teachers stated that the British accent of listening materials seemed problematic, especially for teachers who speak in American English accent in their classes. Students of these teachers got confused about the pronunciation of words due to the teacher's American accent and listening materials' British accent.

Students were really satisfied with the topics of Total English coursebook. They also believed that the coursebook contain very attractive pictures which give them ideas to speak.

\section{Discussion of the Findings}

In the following, each research question is presented and discussed thoroughly.

\subsection{Research Question 1}

How is Total English series viewed from language teachers' and students' perspectives?

In the case of all categories, teachers as well as students had approximately similar ideas. However, some differences could be identified.

In terms of content, contrary to the students' beliefs, teachers believed that pedagogic texts and dialogues in Total English do not include a variety of interesting subjects. Regarding grammar, teachers and students believed that in the coursebook, sentences and examples contain words that are known by learners. Teachers also believed that there is a balance between form and use in Total English. Teachers and student were not satisfied with richness and adequacy of exercises for vocabulary in the coursebook. Moreover, both teachers and students believed that Total English coursebook do not have an adequate amount of pronunciation practice. Considering methodology, students believed that Total English encourages inductive approach to learning and balance accuracy with fluency. In the case of visuals, teachers agreed that Total English has attractive layout. On the other hand, students were not content with the attractiveness of the visuals in the coursebook. In regard to practice and testing, teachers and students believed that Total English provided good explanations regarding how every exercise can be done. With regard to the supplementary materials, teachers believed that the supplementary material such as posters and flash cards, etc. accompanying the book is not attractive and suitable. In terms of objectives, teachers were unanimous that developmental objectives of Total English met the needs of learners. In regard to culture, teachers agreed that Total English is free from ideological tendencies more than the other coursebooks. Also, teachers believed that Total English aim at international culture.

As far as the researcher knows, since no studies regarding the evaluation of Total English coursebook have been carried out, the findings of the present study could not be compared with the relevant previous studies.

\subsection{Research Question 2}

In the following section, the researcher extracted the strengths and weaknesses of the coursebook from both teachers and students point of view based on the amount of mean. The items with the mean more than 3.1 were considered as strength and the items with the mean below 2.4 as weakness. It is worth noting that the items 42,43 and 48 , due to their negative concept, are scored reversely. 


\subsubsection{Strengths of Total English from Students' Perspective}

1. The selected topics are familiar to the students.

2. Pronunciation is built through different types of activities, such as listening, dialogue practice etc.

3. The font size and type used in the book are appropriate.

4. There are directions to explain how every exercise can be done.

Familiarity of topics to students plays a significant role in helping students initiate speaking. Unless the topics were familiar to students, they could not speak even if they had no problem in expressing themselves. From students' point of view, Total English is the coursebook which has such an asset to a large extent.

\subsubsection{Weaknesses of Total English from Students' Perspective}

1. There is not an adequate amount of pronunciation practice.

In spite of the significance of pronunciation in language learning, Total English does not provide adequate amount of pronunciation practice in students' belief. Such a demerit makes teachers take advantage of appropriate supplementary materials.

\subsubsection{Strengths of Total English from Teachers' Perspective}

1. The coursebook does not aim to alienate students from their own culture.

2. It does not take religious considerations into account.

3. It aims at international culture.

\section{Conclusion}

In conclusion, the researcher does not propose that one coursebook should replace another but that teachers should be well aware of strengths and weaknesses of the coursebook they teach. In other words, it is important to consider which coursebook may best support language learners in diverse instructional contexts.

\section{References}

1. Brown, J. (1995). The Elements of Language Curriculum. Boston: Heinle and Heinle Publishers.

2. Cunningsworth, A. (1984). Evaluating and selecting ELT materials. London: Heinemann.

3. Cunningsworth, A. (1995). Choosing your coursebook. UK: Heinemann English Language Teaching.

4. Daud, A., \& Celce-Murcia , M. (1979). Selecting and evaluating textbooks. In M. Celce- Murcia \& L. Mclntosh (Eds.), Teaching English as a second or foreign Language. New York, NY: Newbury House.

5. Garinger, D. (2002). Textbook Selection for the EFL Classroom. Washington DC: ERIC Digest (Dec.).

6. Hutchinson, T. \& Torres, E. (1994). The Textbook as Agent of Change. ELT Journal, 48(4), 315-328.

7. Hutchinson, T., \& Waters, A. (1987). English for specific purposes: A learning-centered approach. Cambridge: Cambridge University Press.

8. Kiely, R. (2009). Small answers to the big question: Learning from language program evaluation. Language Teaching Research, 13(1), 99-116.

9. Lamie, J. M. (1999). Making the textbook more communicative. The Internal TESL Journal, 5(1). Retrieved September 27, 2012, from www.iteslj.org.

10. Litz, D. R. A. (2005). Textbook evaluation and ELT management: a South Korean 46 Iranian EFL Journal case study. Asian EFL Journal. Retrieved from: http://www.asian-efl-journal.com/Litz_thesis.pdf

11. Low, G. (1989). Appropriate design: the internal design of course units. Cambridge: Cambridge University Press.

12. McDonough, J., \& Shaw, C. (2003). Materials and methods in ELT. Oxford: Blackwell.

13. McGrath, I. (2002). Materials Evaluation and Design for Language Teaching. Edinburgh: Edinburgh University Press.

14. Najafi Sarem, S., Hamidi, H., \& Mahmoudie, R. (2013). A Critical Look at Textbook Evaluation: A Case Study of Evaluating an ESP Course-Book: English for International Tourism. International Research Journal of Applied and Basic Sciences, 4 (2), 372-380.

15. Nooreen, N., \& Arshad, A. A. (2010). Examining the importance of EST and ESL textbooks and materials: objectives, content and form. [Online] Available: http://www.esp-world.info/Articles_9/textbooks.htm (January 23, 2011)

16. Razmjoo, S. A. (2007). High schools or private institutes textbooks? Which fulfill communicative language teaching principles in the Iranian context? Asian EFL Journal, 9(4), 126-140. 
17. Richards, J. C. (2001). Curriculum Development in Language Teaching. Cambridge: Cambridge University Press.

18. Richards, J. C., Platt, J., \& Weber, H. (1985). Longman dictionary of applied linguistics. London: Longman.

19. Shatery, H. \& Azargoon, M. (2012). Designing and Developing a Native Checklist to

Evaluate General English Course Books in Iran and Comparing It with Other Existing Checklists in the World. The First Conference on Language Learning and Teaching: An Interdisciplinary Approach, October, 30 and 31, 2012.

20. Sheldon, L. (1988). Evaluating ELT textbooks and materials. English Language Teaching Journal, 42(4), $237-246$.

21. Skierso, A. (1991) . Textbook selection and evaluation. In M. Celce-Murcia (Ed.),

Teaching English as a second or foreign Language. (pp :) Boston : Heinle and Heinle Publishers.

22. Soori, A., Kafipour, R., \& Soury, M. (2011). EFL textbook evaluation and graphic representation. European Journal of Social Sciences, 26 (3), 481-493.

23. Tomlinson, B. (1998). Glossary of basic terms for materials development in language teaching and introduction. In B. Tomlinson (ed.), Materials development in language teaching. (pp. 1-24). Cambridge: Cambridge University Press.

24. Tomlinson, B. (2001). Materials development. In R. Carter and D. Nunan (Ed.), The Cambridge Guide to Teaching English to Speakers of Other Languages. Cambridge: Cambridge University Press.

25. Ur, P. (1996). A course in language teaching: Practice and theory. Cambridge: Cambridge University Press. 